\title{
SOCIAL SECURITY, BENEFIT CLAIMING AND LABOR FORCE PARTICIPATION: A QUANTITATIVE GENERAL EQUILIBRIUM APPROACH
}

\author{
Selahattin İmrohoroğlu and Sagiri Kitao* \\ CRR WP 2010-2 \\ Released: March 2010 \\ Date Submitted: March 2010
}

\author{
Center for Retirement Research at Boston College \\ Hovey House \\ 140 Commonwealth Avenue \\ Chestnut Hill, MA 02467
}

Tel: 617-552-1762 Fax: 617-552-0191

* Selahattin İmrohoroğlu is professor of finance and business economics at the University of Southern California (USC) Marshall School of Business. Sagiri Kitao is an economist at the Federal Reserve Bank of New York. The authors gratefully acknowledge the USC provost's office, the Social Security Administration, and the Center for Retirement Research at Boston College for its support of this research. The research reported herein was pursuant to a grant from the U.S. Social Security Administration (SSA) funded as part of the Retirement Research Consortium (RRC). The opinions and conclusions expressed are solely those of the authors and do not represent the opinions of SSA, any agency of the federal government, the RRC, the Federal Reserve Bank of New York, the Federal Reserve System, or Boston College.

(C) 2010, by Selahattin İmrohoroğlu and Sagiri Kitao. All rights reserved. Short sections of text, not to exceed two paragraphs, may be quoted without explicit permission provided that full credit, including (C) notice, is given to the source. 


\title{
About the Sandell Grant Program
}

This paper received funding from the Steven H. Sandell Grant Program for Junior Scholars in Retirement Research. Established in 1999, the Sandell program's purpose is to promote research on retirement issues by scholars in a wide variety of disciplines, including actuarial science, demography, economics, finance, gerontology, political science, psychology, public administration, public policy, sociology, social work, and statistics. The program is funded through a grant from the Social Security Administration (SSA). For more information on the Sandell program, please visit our web site at http://crr.bc.edu/opportunities/steven_h._sandell_grant_program_2.html, send e-mail to crr@bc.edu, or call Marina Tsiknis at (617) 552-1092.

\section{About the Center for Retirement Research}

The Center for Retirement Research at Boston College, part of a consortium that includes parallel centers at the University of Michigan and the National Bureau of Economic Research, was established in 1998 through a grant from the Social Security Administration. The Center's mission is to produce first-class research and forge a strong link between the academic community and decision makers in the public and private sectors around an issue of critical importance to the nation's future. To achieve this mission, the Center sponsors a wide variety of research projects, transmits new findings to a broad audience, trains new scholars, and broadens access to valuable data sources.

\author{
Center for Retirement Research at Boston College \\ Hovey House \\ 140 Commonwealth Avenue \\ Chestnut Hill, MA 02467 \\ phone: 617-552-1762 fax: 617-552-0191 \\ e-mail: crr@bc.edu \\ crr.bc.edu
}

Affiliated Institutions:

The Brookings Institution

Massachusetts Institute of Technology

Syracuse University

Urban Institute 


\begin{abstract}
We build a general equilibrium model with endogenous saving, labor force participation, work hours and Social Security benefit claiming, in which overlapping generations of individuals face income, survival, and health expenditure risks in incomplete markets. We use the model to study the impact of three Social Security reforms: reductions in benefits and payroll taxes, an increase in the early retirement age from 62 to 64, and an increase in the normal retirement age from 66 to 68 . We show that a reform can have a significant effect on the budget of Social Security through changes in savings as well as benefit claiming and labor force participation. When the projected aging of the population is taken into account, the case for a reform that encourages labor force participation of the elderly becomes stronger.
\end{abstract}




\section{Introduction}

Social Security is facing significant challenges in the near future. Currently, the system runs a surplus; total payroll taxes collected from workers exceed total benefits given to the retirees. However, the population is aging and the projected increase in the dependency ratio will eventually force a reversal of the flow of resources in and out of the retirement fund. According to the 2009 Trustees Report of the Social Security Administration, the unfunded liabilities of Social Security are estimated to be $\$ 17.5$ trillion. A large reduction in benefits or an increase in the payroll tax rate may be required to address the shortfall of the Social Security system.

Meanwhile, historical changes in the Social Security rules and other economic and demographic factors have contributed to two observations that influence the financial balance of the Social Security system. First, there has been an increase in the fraction of individuals retiring early, taking benefits before reaching the normal retirement age. ${ }^{1}$ In 2007, more than $50 \%$ of retirees chose to take permanently reduced benefits at the earliest retirement age of 62 , rather than wait for the normal retirement age or beyond. Second, there has been a decline in the labor force participation rate of old-age individuals, which has been somewhat stabilized recently. According to the Bureau of Labor Statistics, the labor force participation rate for males between the ages of 55 and 64 has declined from $83.0 \%$ in 1970 , to $67.8 \%$ in 1990 and seems to have slightly reversed itself recently, with a projected increase to $69.6 \%$ by 2016 . Female labor force participation in the same age group has increased from $43.0 \%$ in 1970 to $51.9 \%$ in 2000 , countering the negative movement in the male participation rate trends.

This paper develops a quantitative general equilibrium model and attempts to capture the patterns of retirement and labor force participation that emerge from the optimal life-cycle decisions of individuals. Overlapping generations of individuals face income, survival, and health risks in incomplete markets and maximize the life-time utility derived from consumption net of disutility from work and a fixed cost of participation. Our model economy places individuals in an environment with current Social Security rules, including the progressive benefit formula as a concave function of individuals' past earnings, the earnings test, actuarial reduction factor for early retirees and delayed retirement credits for late retirees. Health shocks are calibrated from the Medical Expenditure Panel Survey and the persistence of bad health status and medical expenditures rise with age. Many but not all individuals have access to employer provided health insurance which partially covers the medical expenditures until they become eligible for Medicare at age 65. Medicare provides a universal health insurance for old-age individuals and covers a fraction of their medical expenditures. We target some long run U.S. macroeconomic indicators in our selection of functional forms and parameter values. Our benchmark model generates Social Security benefit claiming and labor force participation behavior that are in line with their observed counterparts in the U.S. data. About $50 \%$ of the individuals retire at age 62 ; by the normal retirement age of 66 , more than $95 \%$ are retired. The early take-up rates of the relatively unhealthy individuals are higher than healthier ones, as suggested by empirical evidence. At the same time, labor force participation rate is relatively flat at

\footnotetext{
${ }^{1}$ Throughout the paper, 'retirement' means the claiming of Social Security benefits and does not mean the exit from the labor market.
} 
the young and middle ages but sharply declines as individuals approach earliest and normal retirement ages. Healthier individuals have higher participation rates than unhealthy ones throughout the life cycle.

We use our model to evaluate the effects of three counterfactual experiments. First, we simulate a Social Security reform that reduces retirement benefits by $50 \%$ and cutting the Social Security payroll tax by half. With increased saving motives for life cycle and precautionary reasons, individuals respond to this reform by raising the capital stock by 10\%. Aggregate labor supply rises by over 3\%, with most of the increase coming from the extensive margin. In particular, the participation rate of older workers, those that are between 60 and 69, increases from $50 \%$ to $62 \%$ and individuals work significantly longer than in the economy with the current system. There is also a significant decline in the fraction of individuals who claim the benefit at the first eligibility age of 62 . We also evaluate the same reform of a benefit reduction in an economy where the demographic structure is the projected one in 2080 and assess the impact of a longer life-expectancy and a higher dependency ratio. The effects are magnified both in terms saving and labor supply since the individuals need additional savings for consumption and medical expenditures for a longer expected life-time. The reform will also help contain the deficit of the program arising from the aging demographics.

Our second experiment raises the earliest retirement age by two years. In this case, most of the macroeconomic indicators remain essentially unchanged, including the Social Security budget. Although the government will 'save' by eliminating the benefits at age 62 and 63, it 'loses' by having to pay higher benefits later on because of the permanent increase in the benefits taken at later ages. In the third policy experiment, we increase the normal retirement age by two years. There is a $2.9 \%$ increase in the capital stock, with a slight $0.7 \%$ increase in labor. The more significant impact is on the fraction of early benefit takers, which declines from $50 \%$ to less than $39 \%$. Combined with a 2.4 percentage point increase in the participation rate of older workers, the Social Security budget improves significantly.

The paper is organized as follows. Section 2 discusses the related literatures and our contribution to them. The model economy is described in Section 3. The calibration of the model is presented in Section 4. Section 5 displays the quantitative findings of the paper. Extensions and sensitivity analyses are presented in Section 6. Section 7 concludes.

\section{Related literature}

Our paper builds on and contributes to a long tradition in macroeconomics that uses largescale, discrete-time overlapping generations models developed by Auerbach and Kotlikoff (1987). In more recent versions, this class of models is amended to incorporate endogenous heterogeneity within cohorts and has become the workhorse in addressing quantitative fiscal policy questions. ${ }^{2}$ Concerning the results of Social Security reform, Hubbard and Judd (1987) and İmrohoroğlu, İmrohoroğlu, and Joines (1995) incorporate liquidity constraints, longevity and individuals income risks and find that an unfunded Social Security system

\footnotetext{
${ }^{2}$ Ríos-Rull (1996) was one of the first to introduce incomplete markets in the Auerbach and Kotlikoff (1987) framework.
} 
significantly reduces the capital stock despite its partial insurance benefit. The economic potential, however, for a welfare enhancing reform becomes difficult or even impossible when transitional costs are explicitly taken into account. ${ }^{3}$ In all of this literature on Social Security and its reforms in the U.S., the decision to claim benefits is taken as exogenous and labor supply, if modeled endogenously, is allowed to adjust only along the intensive margin. ${ }^{4}$ To the best of our knowledge, our paper is the first in this line of literature that allows for endogenous decisions in both benefit claiming and labor force participation and studies how they affect the impact of a reform in the U.S. through the adjustment on these margins.

Recently, health shocks over the life cycle have also been incorporated in this class of models to evaluate the role of medical insurance policies. For example Attanasio, Kitao, and Violante (2009) and Jeske and Kitao (2009) introduce health shocks in a heterogeneous-agent, overlapping generations model and analyze the policies on Medicare and employer-provided health insurance. De Nardi, French, and Jones (2009) build a model of retirees and investigate the role of longevity risk and health expenditure uncertainty on the saving behavior at old ages. These papers demonstrate that health expenditures influence individuals' decisions on consumption and saving over the life cycle and they can also be quite important in a model of Social Security. In particular, the absence of complete insurance for health expenditure shocks may significantly affect choices for retirement and labor force participation. Consequently, we incorporate uncertainty regarding health status and expenditures and how individuals and institutions provide insurance against this additional risk in a model of incomplete markets and explore the implications for retirement and labor market participation behavior of individuals.

There is a second strand of literature following a partial equilibrium tradition that specifies and simulates structural dynamic programming models of life cycle behavior with which we attempt to make contact. Rust and Phelan (1997) develop a dynamic programming model in which individuals face borrowing constraints, idiosyncratic income and health risks, and the Social Security and Medicare rules. Assuming that consumption is equal to income at every age, their model explains the two peaks of retirement given market incompleteness in conjunction with the availability of health insurance and Medicare eligibility. Blau and Gilleskie (2006) find that employer based health insurance has a significant effect on employment of old age individuals.

Following this line of work, French (2005) allows individuals to self-insure against shocks by holding a one-period riskless asset and estimates a model in which individuals choose consumption, saving and labor supply on both intensive and extensive margins. He attempts to explain the pattern of job exits at old ages and studies the roles of Social Security benefit rules. van der Klaauw and Wolpin (2008) incorporate the joint labor supply decision of married couples and study the effects of various counterfactual policies

\footnotetext{
${ }^{3}$ See Huang, İmrohoroğlu, and Sargent (1997), Conesa and Krueger (1999), De Nardi, İmrohoroğlu, and Sargent (1999), and Kotlikoff, Smetters, and Walliser (1999), among others.

${ }^{4}$ There are a few recent exceptions. Díaz-Giménez and Díaz-Saavedrac (2009) build a model of endogenous retirement calibrated to the Spanish economy and study the effects of increasing the retirement age. Rogerson and Wallenius (2009) and Prescott, Rogerson, and Wallenius (2009) introduce a non-linear transformation of hours worked to the labor efficiency to explain the labor force participation along the life-cycle.
} 
on labor supply of singles and married individuals.

Gustman and Steinmeier (2005) use a deterministic partial equilibrium model with preference heterogeneity to explain the two retirement age peaks. In particular, they assume that individuals have different time discount factors and parameters that determine the weight of leisure in the utility function that also change over the life cycle.

Benitez-Sílva et al. (2007) attempt to explain the pattern of Social Security claiming behavior which is concentrated at the earliest claim age of 62 . They show that the rules on the benefit adjustment associated with early retirement and earnings test as well as the uncertainty about the future of Social Security system are the important factors behind the early taking behaviors. ${ }^{5}$

Following this line of literature, we attempt to incorporate the detailed rules of the Social Security into a general equilibrium model as precisely as possible and capture various incentives that affect the optimal decision of benefit claiming and labor participation as well as saving and hours allocations over the life-cycle. We run sensitivity analysis in which we compare the effects of a reform under partial and general equilibrium settings and discuss how incorporating price adjustments will add to the analysis.

\section{Model}

\subsection{Demographics and health status}

The economy is populated by overlapping generations of individuals of age $j=1,2, \ldots, J$. Agents face exogenous uncertainty about their health status $h$. The health status evolves according to the Markov chain between two states of good and bad, $\left\{h^{g}, h^{b}\right\}$, with a transition matrix that depends on age. The lifespan is uncertain and agents of age $j$ in health status $h$ survive until the next period with probability $s_{j, h} . J$ is the maximum possible age and $s_{J, h}=0$ for any $h$. The size of a new cohort grows at rate $n$.

\subsection{Endowment and preferences}

Individuals enter the economy with no assets and are endowed with one unit of time that can be used for either leisure or market work. Individuals' earnings are given as $w \varepsilon_{j} \eta l$, where $w$ is the market wage, $\varepsilon_{j}$ the age-specific productivity, $\eta$ idiosyncratic labor productivity that evolves stochastically and follows a first-order Markov process and $l$ endogenously chosen hours of work.

Individuals value consumption and leisure over the life-cycle and order the sequence of consumption and labor supply according to a utility function $u(c, l)$. They also derive 'warm-glow' utility from leaving bequests, denoted as $u^{B}(\cdot)$. For simplicity, we assume that bequests are collected by the government and distributed as a lump-sum transfer to the entire population, denoted by beq. Individuals discount future utility by a constant rate $\beta$.

\footnotetext{
${ }^{5}$ Benitez-Sílva and Heiland (2007a) focus on the first factor and studies the role of the early retirement penalty on benefits and the option to reduce the penalty by working before reaching the normal retirement age.
} 


\subsection{Medical expenditures and health insurance}

Individuals face medical expenditure shocks every period. Gross medical expenditure $\widetilde{m}$ is a random draw from the distribution $\pi_{j, h}^{m}$ that depends on age and health status. We assume that some individuals are covered by health insurance provided through employers. Let $i \in\{0,1\}$ denote the employer-sponsored health insurance status with $i=1$ indicating the coverage tied to employment and $i=0$ indicating no coverage. A draw at age $j=1$ determines the insurance state $i$ that is fixed throughout life. Since the insurance is tied to employment, individuals will not have the coverage while they choose to completely withdraw from work. The employer-based insurance covers a fraction $\kappa^{h i}$ of gross expenditures. Out-of-pocket expenditures are denoted by $m .{ }^{6}$ Those covered by the insurance pay a premium $p^{h i}$, which we include in the out-of-pocket expenditures $m$.

\subsection{Technology}

The production is undertaken by a representative firm that operates a constant returns to scale technology: $Y=F(K, L)=A K^{\alpha} L^{1-\alpha}$, where $K$ and $L$ are aggregate capital and labor inputs and $\alpha$ is the capital share. $A$ is the total factor productivity which we assume is constant. Capital depreciates at rate $\delta \in(0,1)$. The firm rents capital and labor efficiency units from individuals in competitive markets, where factor prices $r$ and $w$ are equated to the marginal productivities.

\subsection{Social Security}

In the benchmark economy, the government operates a pay-as-you-go pension system similar to the current U.S. system. Working individuals pay a proportional tax $\tau^{s s}$ on their labor income up to the maximum earnings of $y^{s s}$, above which the Social Security tax rate is zero. Each beneficiary receives the benefit $s s$, according to a concave function of an individual's average lifetime earnings denoted by $e$, that captures the progressivity of the U.S. Social Security system. Individuals can begin to receive the Social Security benefit once they reach the earliest claim age $j^{E R A}$, which we call the earliest retirement age. The benefit is adjusted downwards if it is claimed before the normal retirement age of $j^{N R A}$ and upwards if the claim is postponed until after the normal retirement age. If an individual below the normal retirement age works and receives labor income that exceeds the earnings limit while receiving Social Security benefit, part of the benefit is taxed away according to the earnings test. The amount of the earnings tax is denoted by $\tau^{E T}$. In exchange for the benefits withheld, the government will undo the penalty on early retirement by partially restoring the downward adjustment on the benefits. We discuss more details of the earnings test and the benefit adjustment in section 4 . The benefit is constant over the remaining lifespan of an individual, unless it is subject to the adjustment as a result of the earnings test.

\footnotetext{
${ }^{6}$ We define $m$ as the payment net of insurance and Medicare coverage as well as health insurance premium or Medicare premium if the individual is a recipient of the benefits.
} 


\subsection{Medicare}

The government provides health insurance for the elderly through Medicare. Once individuals reach the Medicare eligibility age of $j^{\text {med }}=46$ (65 years old), they are covered by Medicare. ${ }^{7}$ Medicare covers a fraction $\kappa^{\text {med }}$ of gross expenditures. The program is financed by the combination of the Medicare tax $\tau^{\text {med }}$ on earnings, Medicare premium $p^{\text {med }}$ from each benefit recipient and the general government budget.

\subsection{Government transfer}

The government runs a transfer program which guarantees a minimum level of consumption $\underline{c}$ by providing a transfer $\operatorname{tr}$ in case individuals disposable assets fall below $\underline{c}$, as in Hubbard, Skinner, and Zeldes (1995). This policy provides insurance against health expenditures that individuals are unable to repay. It provides the roles of transfer programs such as Medicaid and Supplemental Security Income, that help individuals eliminate medical liabilities.

\subsection{Fiscal policy}

The government raises revenues from taxation on labor income, capital income and consumption at proportional rates denoted by $\tau^{l}, \tau^{k}$ and $\tau^{c}$, Medicare premium from beneficiaries, Social Security and Medicare taxes on earnings, and issuance of one-period riskless debt $D$. The government borrowing and the tax revenues finance the payment of Social Security and Medicare benefits, expenditures for the government transfer program, an exogenously given level of public purchases of goods and services $G$ and the servicing and repayment of the debt. The labor income tax rate $\tau^{l}$ is determined in equilibrium so that the consolidated government budget constraint is satisfied every period.

\subsection{Market structure}

The markets are incomplete and individuals cannot insure against the idiosyncratic labor income and mortality risks by trading state-contingent assets. They can, however, hold one-period riskless assets to imperfectly self-insure against idiosyncratic risks. We assume that agents are not allowed to borrow against future income. For the health expenditure risks, agents are imperfectly protected according to the individual insurance arrangement and Medicare at the old ages.

\subsection{Individuals' problem}

Individuals are heterogeneous in seven dimensions summarized by a state vector $x=$ $\{j, a, \eta, h, i, e, b\}$, where $j$ denotes age, $a$ assets carried over from the previous period, $\eta$ the idiosyncratic labor productivity, $h$ health status, $i$ health insurance coverage and $e$

\footnotetext{
${ }^{7}$ We assume that everyone becomes covered by Medicare at age 65 . We abstract from supplemental insurance besides Medicare and employer-provided health insurance for those eligible for it is replaced by Medicare above age 65 .
} 
the cumulated labor earnings that determine the Social Security benefit. $b$ is an indicator that takes a value 1 if an individual has already applied for Social Security benefit and 0 otherwise. Agents choose $\left\{c_{j}, l_{j}, b_{j}\right\}_{j=1}^{J}$, that is, a sequence of consumption, work hours and Social Security benefit application in order to maximize the life-time utility. ${ }^{8}$

The timing of events is given as follows. At the beginning of each period, each individual is characterized by a state vector $x$. If individual's assets $a$ are not large enough to finance the minimum consumption $\underline{c}$, the government intervenes through its transfer program and makes a transfer $t r$, just enough so that the individual can consume at least the amount $\underline{c}{ }^{9}$ Next, individuals make an optimal decisions of $\left\{c, l, b^{\prime}\right\}$. The choice is made under uncertainty about medical expenditure shocks that hit each individual later in the period. Individuals then consume, supply labor, rent capital and receive wage and interest payments from firms. The earnings based on the choice of labor supply determine the state of cumulated labor earnings $e^{\prime}$ for the next period. Agents receive Social Security benefits if applicable and pay taxes based on the current income and consumption. Then the medical expenditure shocks are realized and individuals are subject to the out-ofpocket payment of $m$, which affects the assets $a^{\prime}$ available at the beginning of the next period. At the end of the period, the idiosyncratic productivity $\eta^{\prime}$ and health status $h^{\prime}$ for the next period and the mortality shock are realized. Conditional on survival, agents receive accidental bequests from the deceased and enter the next period with the new state vector $x^{\prime}=\left\{j+1, a^{\prime}, \eta^{\prime}, h^{\prime}, i, e^{\prime}, b^{\prime}\right\}$.

We compute individuals' problem recursively. The value function $V(x)$ of an individual in state $x$ is given by

$$
V(x)=\max _{c, l, b^{\prime}}\left\{u(c, l)+\beta s_{j, h} E\left[V\left(x^{\prime}\right)\right]+\beta\left(1-s_{j, h}\right) E\left[u^{B}\left(a^{\prime}\right)\right]\right\}
$$

subject to

$$
a^{\prime}=(1+r) k+w \varepsilon_{j} \eta l+s s(x)-m(x)-T(x)+b e q,
$$

where

$$
\begin{aligned}
& k=a-\left(1+\tau^{c}\right) c+t r \geq 0, \\
& t r=\max \left\{0,\left(1+\tau^{c}\right) \underline{c}-a\right\}, \\
& e^{\prime}=f_{j}\left(e, w \varepsilon_{j} \eta l, b^{\prime}\right),
\end{aligned}
$$

where $k$ is the capital rent to firms and $T(x)$ denotes the income and payroll taxes paid by an individual in state $x$ :

$$
T(x)=\tau^{k} r k+\left(\tau^{l}+\tau^{m e d}\right) w \varepsilon_{j} \eta l+\tau^{s s} \min \left\{w \varepsilon_{j} \eta l, y^{s s}\right\}+\tau^{E T} .
$$

The evolution of $e$ is governed by the age-dependent function of labor earnings and Social Security decision, which we detail in section 4.

\footnotetext{
${ }^{8}$ The decision of whether to claim the Social Security benefits can occur only at certain ages as discussed in section 4.5. The indicator $b$ is 0 if the agent is below the first age to be eligible for the Social Security benefit and it is 1 after the last age to apply for the benefit.

${ }^{9}$ Note that depending on the realized medical expenditures in the previous period, $a$ can be negative. The variable $a$ represents total resources available to agents as they enter the new period, as in the cash-on-hand in Deaton (1991).
} 


\subsection{Stationary equilibrium}

For a given set of exogenous demographic parameters $\left\{s_{j}\right\}_{j=1}^{J}$ and $\{n\}$ and government policy variables $\left\{G, D, s s, \tau^{s s}, y^{s s}, \tau^{E T}, t r, \tau^{m e d}, p^{m e d}, \tau^{k}, \tau^{c}\right\}$, a stationary competitive equilibrium consists of individuals' decision rules $\left\{c, l, b^{\prime}\right\}$ for each state $x$, factor prices $\{w, r\}$, private health insurance premium $\left\{p^{h i}\right\}$, labor income tax rate $\left\{\tau^{l}\right\}$, a lump-sum transfer of accidental bequests $\{b e q\}$ and the measure of individuals $\{\mu(x)\}$ that satisfy the following conditions:

1. Individuals' allocation rules solve the recursive optimization problem defined in section 3.10 .

2. Factor prices are determined competitively, i.e. $w=F_{L}(A, K, L)$ and $r=F_{K}(A, K, L)-$ $\delta$.

3. The lump-sum bequest transfer is equal to the amount of assets left by the deceased. ${ }^{10}$

$$
b e q=\sum_{x} a(x)\left(1-s_{j-1, h}\right) \mu(x)
$$

4. Private health insurance premium $p^{h i}$ is determined so that the insurance provider will break even.

$$
p^{h i} \sum_{x \mid i=1, l(x)>0, j<j^{\text {med }}} \mu(x)=\kappa^{h i} \sum_{x \mid i=1, l(x)>0, j<j^{\text {med }}} \tilde{m}(x) \mu(x)
$$

5. The labor and capital markets clear.

$$
\begin{aligned}
L & =\sum_{x} \varepsilon_{j} \eta l(x) \mu(x) \\
K & =\sum_{x} k(x) \mu(x)-D
\end{aligned}
$$

6. The labor income tax satisfies the consolidated government budget constraint.

$$
\begin{aligned}
& G+(1+r) D+\sum_{x} s s(x) \mu(x)+\sum_{x} \operatorname{tr}(x) \mu(x)+\sum_{x \mid x \geq j^{m e d}} \kappa^{m e d} \widetilde{m}(x) \mu(x) \\
= & \sum_{x}\left[\left(\tau^{l}+\tau^{m e d}\right) w \varepsilon_{j} \eta l(x)+\tau^{s s} \min \left\{w \varepsilon_{j} \eta l(x), y^{s s}\right\}+\tau^{k} r k+\tau^{c} c(x)\right. \\
& \left.+p^{\text {med }} I_{\left\{j \geq j^{\text {med }}\right\}}\right] \mu(x)+D^{\prime},
\end{aligned}
$$

where $D$ is the debt issued in the previous period and $D^{\prime}$ is the proceeds of the debt issued in the current period.

\footnotetext{
${ }^{10}$ Note that individuals could die in debt if they were hit by large medical expenditure shocks before dying and were unable to pay the bill. We assume that the government will collect all the assets of the deceased, including the negative ones. In all of our equilibrium computation, the sum never goes negative and the bequest transfer is positive.
} 
7. The goods market clears.

$$
C+K^{\prime}+M+G=Y+(1-\delta) K
$$

where $C=\sum_{x} c(x) \mu(x)$ and $M=\sum_{x} \widetilde{m}(x) \mu(x)$.

\section{Calibration}

This section describes parametrization of the model. Table 3 provides a summary.

\subsection{Demographics}

One model period corresponds to a year. The unit of a model is an individual. We assume that individuals enter the economy at age $20(j=1)$ and live up to the maximum age of $90(J=71)$. We set the growth rate $n$ of the new entrants to the economy to $1.1 \%$, the long-run average population growth in the U.S.

\subsection{Health, medical expenditures and health insurance}

Our main source of micro data related to health status, medical expenditures and health insurance is the Medical Expenditure Panel Survey (MEPS). MEPS is an ongoing annual survey of a representative sample of the civilian population with detailed information on demographics, labor supply, health status, health expenditures and health insurance. We use the most recent panel of individual data to calibrate the health status transition and the distribution of medical expenditures, as well as the coverage provided by health insurance and Medicare. The measure of health status in MEPS is self-reported. Every annual MEPS survey has three waves, and this measure is present in each one. We choose to define two levels of an individual health status: good $\left(h^{g}\right)$ and bad $\left(h^{b}\right)$. First, for each individual, we compute the numerical average of the answer to the subjective health question across the three waves, which ranges from 1 to $5 .{ }^{11}$ We then define an individual to be in bad health that year if the average was strictly above 3 . The transition matrices of the health status for different age groups are reported in Table 2.

In order to capture the long-tail in the distribution of the medical expenditures and a small probability of incurring very large and catastrophic expenditures, we use three expenditure states with uneven measures (top 5\%,35\% and 60\%) for each age and health status. The distribution of medical expenditures by age and health status displayed in Table $1 .{ }^{12}$ The transition matrix for the health status is displayed in Table 2.

\footnotetext{
${ }^{11}$ The exact wording of the survey question on health status is: In general, compared to other people of (PERSON)s age, would you say that (PERSON)s health is excellent (1), very good (2), good (3), fair (4), or poor (5)?

${ }^{12}$ In the computation, we linearly interpolate the medical expenditures and the probabilities of remaining in good and bad health across ages so that the expenditures and transition matrices change smoothly over the life-cycle.
} 
Table 1: Medical expenditures from MEPS by age group and health status (in 2006 US dollars)

\begin{tabular}{|c|l|rrr|}
\hline \multirow{2}{*}{ Age } & Health & $60 \%$ & $35 \%$ & $5 \%$ \\
\hline \multirow{2}{*}{$20-29$} & Good & 111 & 2,137 & 13,875 \\
& Bad & 616 & 6,769 & 30,100 \\
\hline \multirow{2}{*}{$30-39$} & Good & 218 & 2,827 & 18,719 \\
& Bad & 842 & 7,665 & 38,313 \\
\hline \multirow{2}{*}{$40-49$} & Good & 291 & 2,808 & 16,126 \\
& Bad & 1,235 & 11,238 & 62,543 \\
\hline \multirow{2}{*}{$50-64$} & Good & 765 & 5,227 & 28,360 \\
& Bad & 2,509 & 15,953 & 73,619 \\
\hline \multirow{2}{*}{$65-$} & Good & 1,814 & 8,394 & 34,780 \\
& Bad & 4,177 & 21,777 & 76,235 \\
\hline
\end{tabular}

Table 2: Transition probabilities between good health and bad health from MEPS by age group

\begin{tabular}{|c|l|cc|}
\hline Age & & Good & Bad \\
\hline \multirow{2}{*}{$20-29$} & Good & 0.9602 & 0.0398 \\
& Bad & 0.4228 & 0.5772 \\
\hline \multirow{2}{*}{$30-39$} & Good & 0.9600 & 0.0400 \\
& Bad & 0.3182 & 0.6818 \\
\hline \multirow{2}{*}{$40-49$} & Good & 0.9470 & 0.0530 \\
& Bad & 0.2382 & 0.7618 \\
\hline \multirow{2}{*}{$50-59$} & Good & 0.9354 & 0.0646 \\
& Bad & 0.2042 & 0.7958 \\
\hline \multirow{2}{*}{$60-69$} & Good & 0.9259 & 0.0741 \\
& Bad & 0.1447 & 0.8553 \\
\hline \multirow{2}{*}{$70-79$} & Good & 0.8871 & 0.1129 \\
& Bad & 0.1937 & 0.8063 \\
\hline \multirow{2}{*}{$80-$} & Good & 0.8491 & 0.1509 \\
& Bad & 0.1802 & 0.8198 \\
\hline
\end{tabular}

In Figure 1 we display the unconditional probability of being in the bad health state over the life cycle, implied by the transition matrices and the initial distribution of health status from MEPS. 


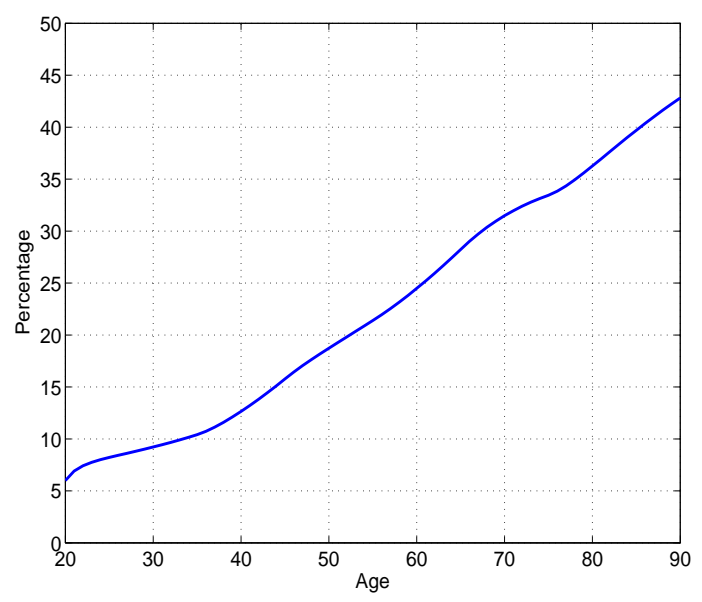

Figure 1: Probability of being in bad health

In order to calibrate health-dependent survival probabilities, we use the methodology developed in Attanasio et al. (2009), who estimate the marginal effect of good health on mortality rates using the Health and Retirement Survey (HRS). The HRS follows samples over a long period of time (seven waves are currently available, each contact being two years apart from the previous one) and it is the ideal sample to estimate mortality rates. ${ }^{13}$

We use the life-table of Bell and Miller (2005) for the current age-dependent conditional survival probabilities in the U.S. and calibrate the health-dependent survival rates so that they are consistent with the estimates in the study. ${ }^{14}$ Let $\bar{s}_{j, h}$ be the average survival rate for age $j$ individuals from the life-table, and $\Lambda_{j}^{h}$ be the distribution of health status at age $j$. Then, given values for $\bar{s}_{j, h}, \Lambda_{j}^{h}\left(h^{g}\right)$ and $\Lambda_{j}^{h}\left(h^{b}\right)$, the following two equations allow to determine the two unknowns $s_{j, h}\left(h^{g}\right)$ and $s_{j, h}\left(h^{b}\right)$ for each age.

$$
\begin{aligned}
\bar{s}_{j, h} & =\Lambda_{j}^{h}\left(h^{g}\right) s_{j, h}\left(h^{g}\right)+\Lambda_{j}^{h}\left(h^{b}\right) s_{j, h}\left(h^{b}\right) \\
\text { survprem }_{j} & =s_{j, h}\left(h^{g}\right)-s_{j, h}\left(h^{b}\right),
\end{aligned}
$$

where survprem $_{j}$ is the above-mentioned good health premium on survival rate for age $j$ individuals estimated from the HRS. Figure 2 shows the conditional survival probabilities by age and health status that we use in our benchmark model.

\footnotetext{
${ }^{13}$ MEPS is a collection of two-year panels and individuals drop out of the sample when they become institutionalized (e.g. enter a nursing home) and are not followed thereafter. Therefore the number of individuals who are recorded as deceased in the survey is extremely small.

${ }^{14}$ We take the average of male and female survival rates from the life-table of 2010.
} 


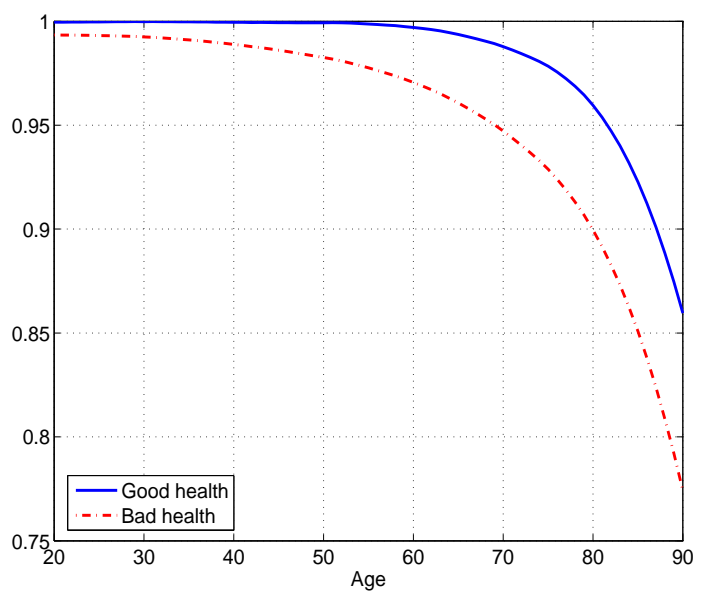

Figure 2: Conditional survival probability by health status

We assume that $70 \%$ of individuals have an access to the employer provided health insurance, which covers a fraction $\kappa^{h i}=70 \%$ of gross expenditures.

\subsection{Endowment and preferences}

The deterministic age-dependent labor productivity $\varepsilon_{j}$ is taken from Hansen (1993) and displayed in Figure 3. We assume that $\varepsilon_{j}=0$ for $j \geq 51$ (70 years old), i.e. no one will work after age 70 .

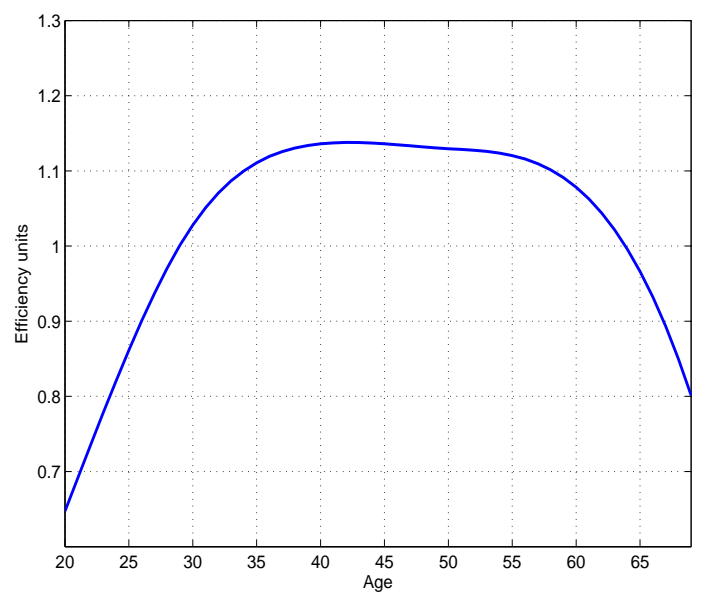

Figure 3: Age-specific labor efficiency profile from Hansen (1993)

The idiosyncratic component $\eta$ is specified as a first-order autoregressive process in log with a persistence parameter $\rho_{\eta}=0.97$ and the variance of the white noise $\sigma_{\eta}^{2}=0.018$, based on the estimates in Heathcote, et al. (2008). ${ }^{15}$ We approximate this continuous process with a five-state, first-order discrete Markov process.

\footnotetext{
${ }^{15}$ For the variance, we use the average of their estimates over 1991-2000. We assume that agents enter
} 
We assume the following period utility function.

$$
u(c, l)=\log c-\chi \frac{l^{1+\frac{1}{\gamma}}}{1+\frac{1}{\gamma}}-\phi(h) \cdot I_{\{l>0\}}
$$

$\chi$ determines the preference weight on the disutility from an extra hour of work relative to consumption utility, which we calibrate so that workers on average spends one-third of their disposable time for market work. $\gamma$ is the Frisch elasticity of labor supply and we set it to 0.5. See Appendix C for more on the calibration of this parameter and sensitivity analysis. $\phi(h)$ represents the fixed cost of labor participation that depends on health status and $I_{\{l>0\}}$ is an indicator function that takes a value of 1 if the agent participates in the market work and 0 otherwise. We calibrate the cost of participation $\phi(h)$ for the two health states to match the overall participation rate of the elderly and the ratio of the participation rates of agents in different health states. ${ }^{16}$ According to the MEPS data, approximately $50 \%$ of individuals between age 60 and 69 participate and work at least 10 hours per week on average. The ratio of participation rates in good and bad health is about 2 . We set $\phi\left(h^{g}\right)=0.5$ and $\phi\left(h^{b}\right)=0.9$ to match these statistics.

Utility from leaving bequest $a^{\prime}$ is defined as

$$
u^{B}\left(a^{\prime}\right)=\psi_{1} \log \left(\psi_{2}+a^{\prime}\right) .
$$

The parameter $\psi_{1}$ represents the weight on the utility from bequeathing, which we calibrate so that the ratio of the wealth held by the individuals aged above 75 to that of the all individuals is 1.8. ${ }^{17} \psi_{2}$ determines the curvature of the utility from bequeathing. We set it to $\$ 500,000$, following De Nardi (2003) and French (2005).

The subjective discount factor $\beta$ is set so that the capital-output ratio in the benchmark model is 2.5. The measure is based on private fixed capital and includes the stock of durables, with the service flows from the stock of durables added to measured output.

\subsection{Technology}

The income share of capital $\alpha$ is set at $0.36 .{ }^{18}$ The depreciation rate $\delta$ is $0.089=\frac{X / Y}{K / Y}-n$, which is implied by the equilibrium law of motion for the capital in the steady state, where we target an investment-output ratio $X / Y$ of 0.25 and a capital-output ratio $K / Y$ of 2.5. The scale parameter $A$ is used for normalization so that the average income in the benchmark economy is unity.

the economy with a common value of $\eta$, which is the log-average of the stationary distribution implied by the Markov process.

${ }^{16}$ We chose to target the elderly participation rather than that of younger generations or of all workers, since the model tends to overestimate the participation of the young. See section 5.1 for more discussion.

${ }^{17}$ The Statistical Abstract of the United States, 2009, Table 699.

${ }^{18}$ Consistent with the target capital-output ratio, this measure is based on private fixed capital including the stock of durables. 


\subsection{Government}

Social Security: The Social Security benefit is computed as a concave function of an individual's average past earnings, $e$. This is a compromise against the actual formula, in which the average earnings index is computed based on the 35 highest earnings years, given that we are unable to keep track of all the 35 earnings. The average past earnings $e$ is capped above at $\$ 102,000$ in 2008 , which is the same level as the maximum amount of earnings subject to Social Security taxation. Workers' Primary Insurance Amount (PIA) is computed using a piecewise linear function of $e$ with three bend points. In 2008, the formula is given as follows. ${ }^{19}$

$$
P I A= \begin{cases}0.9 \times e & \text { if } e<\$ 8,532 \\ \$ 7,679+0.32 \times(e-\$ 8,532) & \text { if } \$ 8,532 \leq e<\$ 51,456 \\ \$ 21,414+0.15 \times(e-\$ 51,456) & \text { if } e \geq \$ 51,456\end{cases}
$$

The above PIA formula applies if an individual first applies and receives the benefit at the normal retirement age of 66. Individuals are eligible to apply for Social Security once they reach the earliest retirement age of 62 . Early receipt, however, permanently reduces the benefit by the Actuarial Reduction Factor (ARF). The PIA of early takers are reduced by $25 \%, 20 \%, 13.3 \%$ and $6.7 \%$ for each age between 62 and 65 . Individuals who initiate the claim at age 66 or above are rewarded through the Delayed Retirement Credit (DRC) and benefits are raised by $8.0 \%$ for every year up to age 70 , when the benefit reaches $132 \%$ of the PIA. ${ }^{20}$ Individuals decide when to begin collecting benefits between age 62 to 70 . After age 70, everyone receives Social Security benefit.

According to the earnings test, part of Social Security benefits can be taxed away if earnings of a benefit recipient below the normal retirement age exceed a certain exempt level. In 2008, the earnings threshold is $\$ 13,560$ and $\$ 1$ of benefits for every $\$ 2$ of earnings in excess of the exempt amount is withheld until all the Social Security benefits are exhausted. The less well known feature of the Social Security system associated with the earnings test that we also incorporate in our model is the following. In order to account for the benefits withheld due to the earnings test, the benefit entitlement is adjusted upwards once they reach the normal retirement age. Individuals can receive the benefits thereafter as if they had not claimed the portion of the benefits prior to the normal retirement age. To capture this adjustment of "undoing" the early retirement penalty, we adjust the state variable $e$, which summarizes the past earnings and determines the benefit level, according to the fraction of the benefit withheld due to the earnings test and to the ARF for early retirement. ${ }^{21}$ Earnings at or above the normal retirement age are not subject to

\footnotetext{
${ }^{19}$ The benefit $(P I A)$ is capped above since $e$ is capped. The maximum PIA is $\$ 28,995.6$ when $e$ is at $\$ 102,000$.

${ }^{20}$ The normal retirement age has been gradually raised and the normal retirement age of 66 and above adjustment rates apply to individuals born in 1943-54. For those individuals born after 1954, the normal retirement age will rise by 2 months for each birth year and it will be 67 for persons born in and after 1960. For details, see http://www.ssa.gov/OACT/ProgData/ar_drc.html.

${ }^{21}$ Note that this is an approximation of the actual adjustment, in which the rise in benefits by having the benefit withheld does not begin until the recipient reaches the normal retirement age. In order to save the cost of keeping track of when the initial claim was made and how much was withheld, we assume that the adjustment is reflected in the immediate increase in the benefit entitlement. We do, however,
} 
the retirement test. ${ }^{22}$

Medicare: Medicare covers $\kappa^{\text {med }}=50 \%$ of the gross medical expenditures of eligible individuals. Each Medicare beneficiary pays the annual Medicare premium $p^{\text {med }}$ of $\$ 1,156.8 .^{23}$ The Medicare tax rate $\tau^{\text {med }}$ on earnings is $2.9 \%$.

Government transfer: The minimum consumption floor $\underline{c}$ is set at $\$ 3,000$. The value is close to Palumbo (1999) (\$2,000 in 1985) and De Nardi, French, and Jones (2009) $(\$ 2,700$ in 1998).

Taxes, expenditures and debt: We set the government spending $G$ at $20 \%$ of output, which is the average ratio of government consumption expenditures and investment to GDP in the post-war period. The ratio of federal debt held by the public to GDP is set at $40 \%$. The capital income tax is set at $30 \%$. We set consumption tax at $5 \%$ based on Mendoza, Razin, and Tesar (1994). The labor income tax rate is determined endogenously so that the government budget constraint is satisfied.

try to capture the time cost associated with the later adjustment by using the ARF. For example, a $\$ 1$ rise in the benefit starting at the normal retirement age of 66 would correspond to the rise of the benefit entitlement at age 63 by 80 cents, given the ARF for the age 63 retirement is $80 \%$.

See Benitez-Sílva and Heiland (2007a) and Benitez-Sílva and Heiland (2007b) for more on this rule and its incentive effects.

${ }^{22}$ The earnings test above age 65 was repealed in 2000. A different rate is applied for the earnings in the year before the month of reaching the normal retirement age. In 2008, $\$ 1$ in benefits for every $\$ 3$ of earnings in excess of a higher amount of $\$ 37,680$ is withheld. Our model is in annual frequency and we abstract from this milder penalty at the normal retirement age.

${ }^{23}$ It accounts for the Medicare part B monthly premium of $\$ 96.4$ in 2008. 
Table 3: Parameters of the model

\begin{tabular}{|c|c|c|}
\hline Parameter & Description & Values/source \\
\hline \multicolumn{3}{|c|}{ Demographics } \\
\hline$n$ & population growth rate & $1.1 \%$ \\
\hline$\left\{s_{j}\right\}_{j=1}^{J}$ & conditional survival probabilities & Bell and Miller (2005), HRS \\
\hline & maximum age & 71 (90 years old) \\
\hline \multicolumn{3}{|l|}{ Preference } \\
\hline$\beta$ & subjective discount factor & 0.964 \\
\hline$\chi$ & weight on leisure & 31.0 \\
\hline$\gamma$ & Frisch elasticity of labor supply & 0.50 \\
\hline$\phi$ & cost of labor force participation & $\{0.5,0.9\}$ \\
\hline$\psi_{1}$ & weight on bequest utility & 27.0 \\
\hline$\psi_{2}$ & curvature of bequest utility & $\$ 500,000$ \\
\hline \multicolumn{3}{|c|}{ Labor productivity process } \\
\hline$\rho_{\eta}$ & persistence parameter & 0.97 \\
\hline$\sigma_{\eta}^{2}$ & variance & 0.018 \\
\hline \multicolumn{3}{|c|}{ Technology and production } \\
\hline$\alpha$ & capital share of output & 0.36 \\
\hline$\delta$ & depreciation rate of capital & $8.9 \%$ \\
\hline$A$ & scale parameter & 1.61 \\
\hline \multicolumn{3}{|c|}{ Health insurance } \\
\hline$\kappa^{h i}$ & expenditure coverage rate & $70.0 \%$ \\
\hline$p^{h i}$ & health insurance premium & $\$ 2,115$ \\
\hline \multicolumn{3}{|c|}{ Medical expenditures } \\
\hline$\pi_{j, h}^{m}$ & distribution of medical expenditures & MEPS \\
\hline \multicolumn{3}{|c|}{ Government } \\
\hline$\tau^{k}$ & capital income tax & $30.0 \%$ \\
\hline$\tau^{c}$ & consumption tax rate & $5.0 \%$ \\
\hline$\tau^{l}$ & personal labor income tax rate & $21.5 \%$ \\
\hline$G$ & government purchases & $20 \%$ of GDP \\
\hline$D$ & government debt & $40 \%$ of GDP \\
\hline$\tau^{s s}$ & Social Security tax rate & $10.6 \%$ \\
\hline$j^{N R A}$ & normal retirement age & 47 (66 years old) \\
\hline$j^{E R A}$ & early retirement age & 43 (62 years old) \\
\hline \multirow[t]{3}{*}{$y^{s s}$} & Social Security maximum taxable earnings & $\$ 102,000$ \\
\hline & earnings test threshold & $\$ 13,560$ \\
\hline & earnings test tax rate & $50 \%$ \\
\hline$\tau^{\text {med }}$ & Medicare tax rate & $2.9 \%$ \\
\hline$p^{\text {med }}$ & Medicare premium & $\$ 1,157$ \\
\hline$\kappa^{\text {med }}$ & Medicare expenditures coverage rate & $50.0 \%$ \\
\hline$j^{\text {med }}$ & Medicare eligibility age & 46 (65 years old $)$ \\
\hline$\underline{c}$ & consumption floor & $\$ 3,000$ \\
\hline
\end{tabular}




\section{$5 \quad$ Numerical results}

In this section, we will present the life-cycle decision profiles of individuals and macroeconomic variables in the economy that we modeled and calibrated to approximate the U.S. economy, in which the government operates a pay-as-you-go Social Security system as described in section 3. We call this economy as the benchmark economy. We will then simulate the model with alternative Social Security systems in order to assess the effects of reforms. One of our major focuses in the analysis will be on the labor participation and retirement decision of individuals.

\subsection{Benchmark model}

Figure 4(a) compares the retirement (Social Security benefit claim) in data (SSA, 2007) and the benchmark model. The data is based on the SSA's Annual Statistical Supplement of 2008 for the retirement statistics in $2007 .{ }^{24}$ As we discussed in section 1, majority of individuals claim benefits at the earliest retirement age of 62 in the data. Our model captures the fraction of earliest retirees well and approximately $50 \%$ of them initiate the claim at 62 . By the time individuals reach the normal retirement age of 66 , more than $95 \%$ of individuals will have started to receive benefits both in the model and data. As we show in the various sensitivity analysis, this early claiming behavior of individuals is robust to most of the changes in the model features, although the sensitivity differs quantitatively across the elements of the model. For example, the probability of early retirement is not affected by the degree of health expenditures shocks, level of the consumption floor and bequest motives, but it is more sensitive to the level of health expenditures or availability of Medicare. See Appendix B.

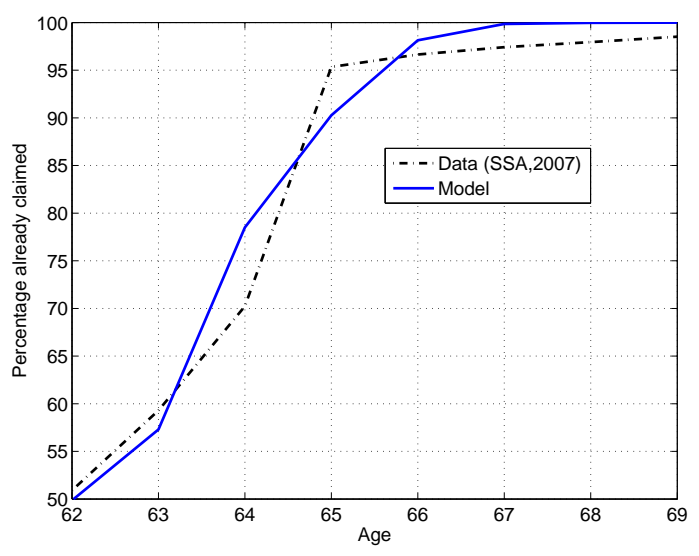

(a) Model vs data

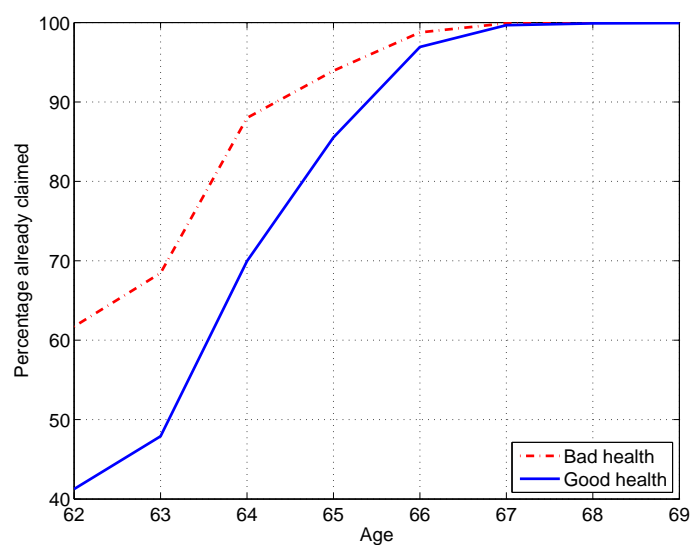

(b) By health status (model)

Figure 4: Social Security benefit entitlement

\footnotetext{
${ }^{24}$ Consistently with the numbers reported in SSA's Annual Statistical Supplement, the plot for the model in Figure 4(a) represents the fraction of all retirees whose initial entitlement is at a particular age. The right panel, Figure 4(b), for the retirement by health status is based on the fraction of individuals in particular age and health status that are already retired.
} 
One way to understand the pattern of claiming behavior is to examine how the agents in the model perceive the benefit adjustment factors for early and late retirement (ARF and DRC) according to the current Social Security rules. Figure 5 compares the $\mathrm{ARF}$ and DRC of the Social Security system and actuarially fair adjustment factors of the benefits for the claims initiated at ages between 62 and 70, in which we assume the average survival rates of 2010 from Bell and Miller (2005) and the equilibrium interest rate in our benchmark model for discounting the future benefits. We normalize the factors by the level of benefits at the normal retirement age.

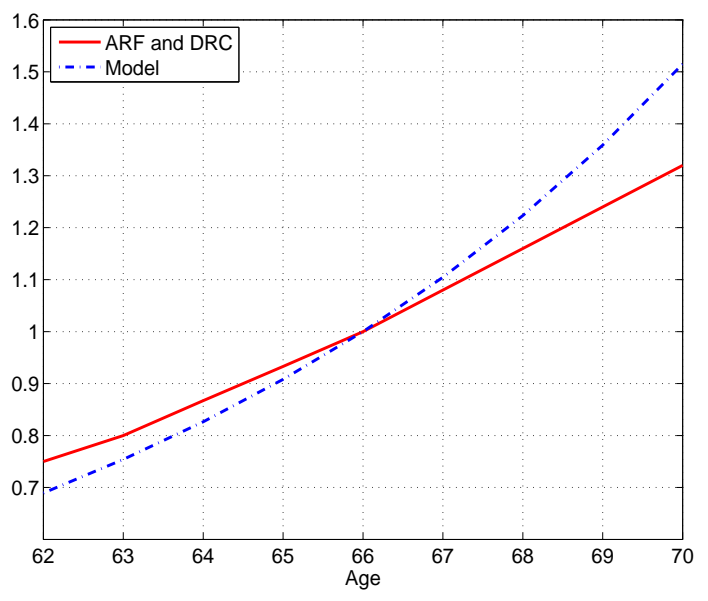

Figure 5: ARF/DRC and actuarially fair adjustment factors of the model

As shown in Figure 5, the ARF relative to the benefits initially claimed at the normal retirement age of 66 is more than actuarially fair. There would be an incentive to claim benefits before the normal retirement age, provided that all individuals faced the same average survival rates and there was a complete market. However, under incomplete markets, the value of social security is not simply the present value of the benefits based on the average survival rates. Given the uninsurable uncertainty in old ages (longevity and medical expenditure risks) and the level of expenditures that have to be paid if they live longer than expected, the higher annuity value of social security that one can obtain by postponing the retirement may be more appreciated than its actuarial value.

So who would value an additional annuity provided by social security more? First, people who expect to live longer than average would value such an annuity. Figure 4(b) displays the benefit claim by health status. Our model implies that unhealthy individuals are more likely to claim benefits early. This is mainly due to the difference in the life expectancies between individuals in good and bad health status whereas the early retirement penalty is common across individuals of the same age. Waldron (2004) combines the data from the Survey of Income and Program Participation (SIPP) and Social Security administrative data and reports the health status distribution of different groups by the age of first entitlement. She finds that the health of early takers is worse than the postponers at the time of their retirement. $67 \%$ of individuals who retire at 62 are in good health, while the fraction increases to $75 \%$ among age 65 retirees. The corresponding 
figures in our model are $66 \%$ and $80 \%$ and we capture the tendency of the heterogeneous health quality among new retirees at different ages. We also point out, however, that the unhealthy individuals will incur much higher expenditures if they survive until the very old ages and they have to weigh the risk of living longer against the expected duration of retirement periods to collect benefits. The net effect depends on the magnitude of both forces and our model suggests that the latter will dominate and induce the unhealthy to claim benefits earlier than later, consistently with data.

Second, poor individuals with lower buffer stock savings against shocks would more appreciate the additional insurance. For them, the annuity value of social security is large and they have an incentive to delay the claiming and raise the permanent benefit. The average assets of early takers at age 62 is $45 \%$ higher than the postponers in the model. It is consistent with the empirical study of Burkhauser et al. (1996) that finds much larger net worth held by early takers than postponers. Note that, however, part of the uncertainty is alleviated by Medicare, which covers half of the medical expenditures as long as they live. In one of the sensitivity analysis in Appendix B, we simulate the model in which we eliminate Medicare entirely and expose individuals to more expenditure risks at old ages. As a result, the benefit claim at 62 will fall from $49.8 \%$ to $43.8 \%$. When we completely eliminate medical expenditures from the model. The claim at 62 in this experiment will rise by $10 \%$.

Third, those who intend to work above a certain level may want to postpone the claim of benefits in order to avoid the earnings test. According to the sensitivity analysis, about $3 / 4$ of individuals would claim benefits at 62 if there were no earnings test.

Figure 6 compares the labor participation in the MEPS data and the benchmark model, overall and by health status. The data are based on the individual data of the MEPS in 2006, where they are asked about their employment status during the interview year. We treat an individual as non-participating if the average hours of work is not more than 10 per week. ${ }^{25}$ The profile in the data is very flat before mid 50s, at which point the participation rate starts to decline, eventually reaching below $30 \%$ in late 60 s. Our model generates a slightly higher participation rates among the young individuals at ages 20 s and 30s, partly because we do not capture some of the reasons such as human capital investment or the time for child-bearing that may prevent individuals from participating. The model generates a sizeable decline in labor force participation starting in early $60 \mathrm{~s}$. 26 The large drop at age 62 corresponds to the age of the earliest retirement, where $50 \%$

\footnotetext{
${ }^{25}$ In terms of the MEPS data, we exclude full-time students. Unemployed individuals would be categorized as non-participating, but since we treat an individual as participating if she worked in at least one of the three sub-year survey periods, most of those who experienced an unemployment spell are categorized as participating given that the average unemployment duration is much shorter than a year in the year the survey was conducted.

Also note that we do not have unemployment in the model and labor force participation rate is defined as those who work more than the cutoff level divided by the population.

${ }^{26} \mathrm{We}$ also underestimate the decline in participation that starts at around age 55 in the data. We conjecture that additional disincentive to participate provided by the features of defined benefit pension plans may help to fill the gap. See Ippolito (1997) on the incentives to quit jobs early given by typical defined benefit pension plans. We chose not to model defined benefit pension plans and other forms of pensions in the current paper mainly for computational difficulties, and we leave the issues of private pensions for future research.
} 
of individuals start to claim benefits as we saw in Figure 4(a). The participation rate also declines sharply at age 65 . This is the age when everyone becomes eligible for the Medicare coverage. We will explore the role of Medicare and health insurance further in the sensitivity analysis of Appendix B.

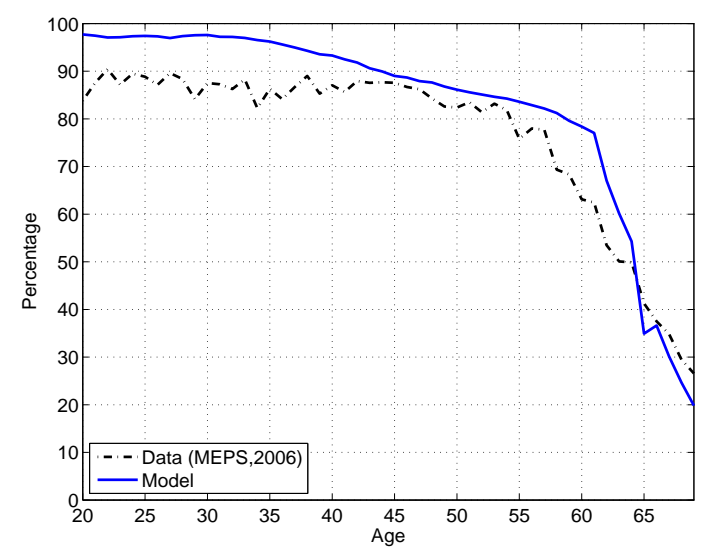

(a) Model vs data

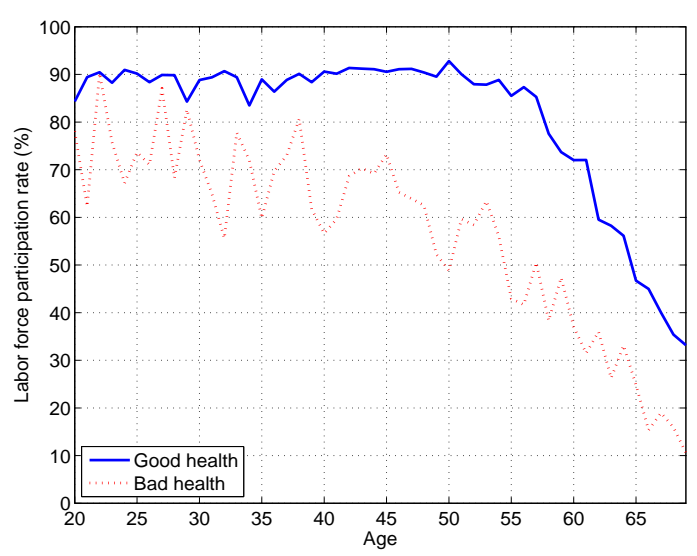

(b) By health status (data)

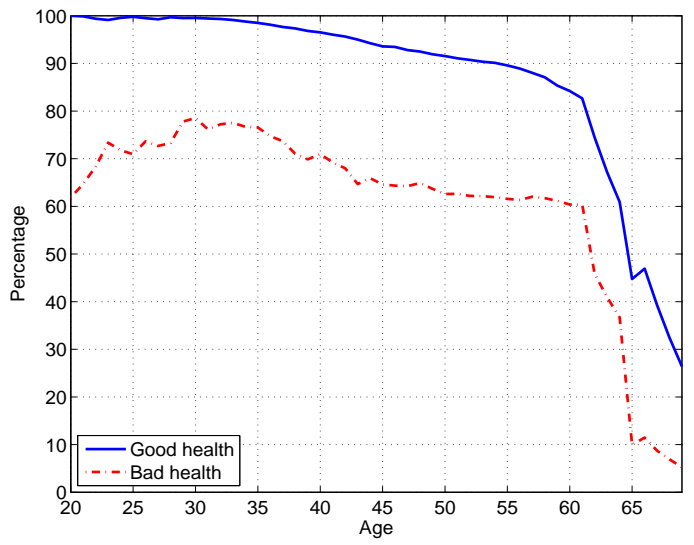

(c) By health status (model)

Figure 6: Labor force participation

Figure 7 displays the average assets by age over the life-cycle. In a life-cycle model with income uncertainty, individuals accumulate savings even in the very early stage of a life-cycle. In our model, they do so for two main reasons, in order to accumulate bufferstock savings against the uncertainty about the income and health expenditures and to build the stock of savings for old-age consumption, as in Gourinchas and Parker (2002). Our model also captures the fact that individuals continue to possess a significant amount of wealth at the very old ages, as documented in De Nardi et al. (2009). Although our model does not attempt to generate the extreme concentration of wealth at the very top wealthiest individuals in the U.S., where $1 \%$ wealthiest own $35 \%$ of the wealth held by all the households (Budría Rodríguez et al, 2002), we capture a fair amount of wealth inequality. Individuals in the top, second and third quintile of wealth distribution own $57 \%, 84 \%$ and $95 \%$ of the entire wealth respectively, and the corresponding data in the 
U.S. are $82 \%, 94 \%$ and $99 \%$ according to the study of Budría Rodríguez et al. (2002).

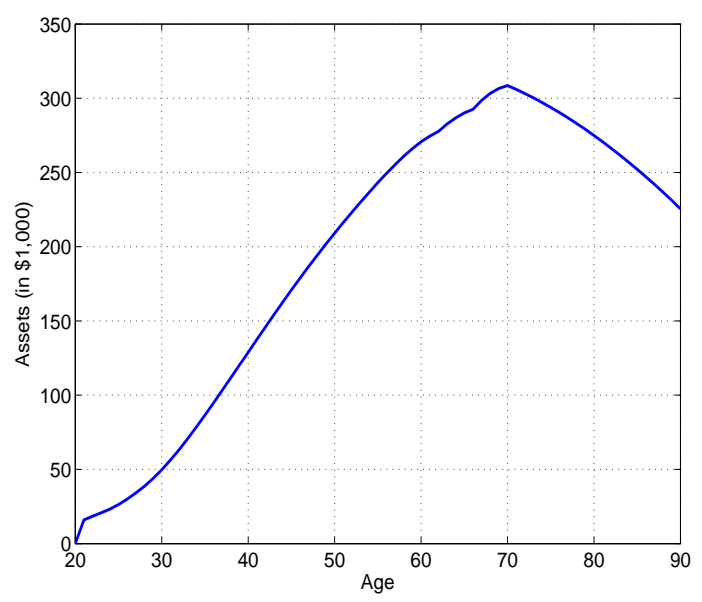

Figure 7: Assets (model)

\subsection{Policy experiments}

In this section, we will study the effects of three policy experiments. In the first experiment, the Social Security tax $\tau^{s s}$ is reduced from $10.6 \%$ to $5.3 \%$ and the Social Security benefit is reduced by $50 \%$. We will preserve the concavity of the benefit functions and three bend points of the PIA formula in (13), but cut the slopes of the function by one half. Individuals are now forced to accumulate more savings in order to support their consumption at old ages. As shown in the Table 4, the reform brings about a significant rise in aggregate capital in the order of $10 \%$. Individuals have much stronger saving motives to finance their old-age consumption and the average assets when they reach the earliest retirement age will rise by $18.8 \%$ from the benchmark economy.

The total tax that combines the labor income tax, Social Security and Medicare taxes falls from $35.0 \%$ to $28.1 \%$. Labor supply increases by approximately $3 \%$, and most of the adjustment comes from an increase in the extensive margin. Since capital becomes more abundant relative to labor inputs, the interest rate falls by about 0.5 percentage point and the wage rate rises by $2.4 \%$. The balance of the Social Security budget is computed as the Social Security taxes collected minus the total spending for the benefits. Although the scope of the program in terms of the benefit and the payroll tax is reduced in half, the budget surplus is $0.3 \%$ of GDP and exceeds one half of that under the benchmark economy, since the increase in labor supply in both extensive and intensive margins and the higher wage rate contribute to more revenues from the payroll taxes.

The labor force participation of the individuals at age 60-69 rises significantly from $49.8 \%$ to $61.5 \%$. Fewer individuals will start collecting Social Security benefits at the earliest retirement age of 62 and many will delay retirement. Postponing the benefit claim will raise the permanent benefit level according to the ARF and DRC and supplement the reduced annuity value provided by Social Security. In İmrohoroğlu and Kitao (2009), where we abstracted from the participation decision and assumed an exogenous fixed 
retirement age, we found that a benefit reduction of the same magnitude will have only a very small impact on the labor supply, in the order of $0.1 \%$ to $0.3 \%$ across different utility specifications. The change in the aggregate capital was of a similar magnitude, in the range of $9 \%$ to $11 \%$. Allowing for the adjustment in the extensive margin generates a large change in both capital and labor, which amplifies the positive effect on output.

The second experiment raises the earliest retirement age by two years, from 62 to 64. As shown in the second to the last column of Table 4, there is no significant change in macro aggregates. The aggregate capital and labor will rise but only by $0.11 \%$ and $0.18 \%$ respectively. The labor income tax remains almost unchanged. The balance of the Social Security budget will improve, but only slightly from a surplus of $0.48 \%$ of GDP to $0.54 \%$. Although the government will save by not having to pay benefits to individuals of age 62 and 63, their benefits will be permanently higher and offset the positive fiscal effect of fewer early retirees.

The third experiment is to raise the normal retirement age by two years, from age 66 to 68 . Individuals will have to wait to claim the benefits until age 66 in order to be entitled to receive the full benefit for the rest of their lives. Early retirement prior to age 66 will result in the reduction of the benefit as in the benchmark economy, according to the adjustment factor implied by the ARF and DRC schedule. ${ }^{27}$ The last column of Table 4 shows the effects of the policy. More individuals will postpone the benefit claim and $39.3 \%$ of retirees take up the benefit at age 62 , compared to $49.9 \%$ in the benchmark economy. The old age participation at 60-69 years old will rise by $2.4 \%$ and aggregate labor supply will slightly rise by $0.7 \%$. There is a significant improvement in the Social Security budget and the surplus will increase to 1.32\% of GDP. Not only does the benefit spendings decline, but also the revenues from the Social Security tax will rise since both the wage and labor supply will increase.

\footnotetext{
${ }^{27}$ In the benchmark economy, the benefits are $75 \%, 80 \%, 86.7 \%, 93.3 \%, 100 \%, 108 \%, 116 \%, 124 \%$ and $132 \%$ at each age of retirement from 62 to 70 (relative to the full benefit according to the PIA schedule). All of these will be adjusted by a factor of $1 / 1.16$, so that the benefit will be $100 \%$ for retirees at age 68 , $64.6 \%(=75 / 1.16)$ at $62,114.8 \%(=132 / 1.16)$ at 70 , etc.
} 
Table 4: Effects of Social Security reforms

\begin{tabular}{|c|c|c|c|c|}
\hline & Benchmark & $\begin{array}{l}\text { Benefit } \\
50 \% \Downarrow\end{array}$ & $\begin{array}{c}\text { ERA } \\
62 \rightarrow 64\end{array}$ & $\begin{array}{c}\text { NRA } \\
66 \rightarrow 68\end{array}$ \\
\hline Aggregate capital & - & $+9.9 \%$ & $+0.11 \%$ & $+2.4 \%$ \\
\hline Aggregate labor & - & $+3.1 \%$ & $+0.18 \%$ & $+0.7 \%$ \\
\hline Average work hours & - & $+0.2 \%$ & $-0.04 \%$ & $+0.1 \%$ \\
\hline Wage & - & $+2.4 \%$ & $-0.10 \%$ & $+0.6 \%$ \\
\hline Interest rate $(\%)$ & $5.54 \%$ & $4.95 \%$ & $5.56 \%$ & $5.39 \%$ \\
\hline Labor income tax: $\tau^{l}+\tau^{s s}+\tau^{\text {med }}(\%)$ & $35.0 \%$ & $28.1 \%$ & $34.9 \%$ & $33.2 \%$ \\
\hline Social Security budget balance (\% of GDP) & $+0.48 \%$ & $+0.30 \%$ & $+0.54 \%$ & $+1.32 \%$ \\
\hline Average assets at 62 (in $2008 \$ 1,000)$ & $\begin{array}{r}277.6 \\
-\end{array}$ & $\begin{array}{r}329.8 \\
+18.8 \% \\
\end{array}$ & $\begin{array}{r}278.9 \\
+0.5 \% \\
\end{array}$ & $\begin{array}{r}292.8 \\
+5.5 \% \\
\end{array}$ \\
\hline \multicolumn{5}{|l|}{ Retirement (Social Security already claimed) } \\
\hline at 62 & $49.9 \%$ & $29.6 \%$ & - & $39.3 \%$ \\
\hline by 66 & $98.1 \%$ & $95.7 \%$ & $97.9 \%$ & $87.4 \%$ \\
\hline by 69 & $100.0 \%$ & $100.0 \%$ & $100.0 \%$ & $100.0 \%$ \\
\hline \multicolumn{5}{|l|}{ Labor force participation } \\
\hline Age $60-69$ & $49.8 \%$ & $61.5 \%$ & $52.4 \%$ & $52.2 \%$ \\
\hline Age 20-59 & $92.5 \%$ & $93.9 \%$ & $92.3 \%$ & $92.9 \%$ \\
\hline
\end{tabular}

\section{Sensitivity analysis and extensions}

This section discusses sensitivity of the quantitative results to alternative scenarios about the demographics and price adjustments. Three sections of the Appendix present additional sensitivity analysis with respect to various features of the model such as rules that determine the Social Security benefit, uncertainty about the reform, the amount of medical expenditures and labor supply elasticity.

\subsection{Effects of demographic change and Social Security reforms}

In this section, we study the effects of the projected demographic change and present a sensitivity analysis of the reform experiments under the aged economy. Instead of assuming the demographic structure summarized by the current survival rates and population growth, we simulate the reforms using the demographic variables for 2080, based on projected conditional survival rates and the projected dependency ratio in 2080. We use the survival rates of 2080 based on the projection in Bell and Miller (2005) and set the population growth rate at $0.1 \%$, which together imply an old-age dependency ratio of about $40 \%$, nearly twice as large as the ratio in the benchmark economy.

Before analyzing the effects of reforms, we discuss the changes in the economy due to the aging of the population, where the current Social Security system is maintained. 
We call the economy with the projected demographic structure as the economy with aging. The results of the benchmark economy with aging are summarized in Table 5 . The increase in longevity and a higher dependency ratio deteriorates the Social Security budget and the annual deficit of the program will reach $3.47 \%$ of GDP. The combined earnings tax will increase by more than 8 percentage points to $43.6 \%$. The relative size of working population falls and both per-capita labor and capital falls significantly by approximately 10\%. Since the annuity value of Social Security will rise with improved survival rates, fewer individuals will choose to retire at the earliest retirement age.

Table 5: Effects of demographic change: economy with aging

\begin{tabular}{|c|c|c|}
\hline & Benchmark & $\begin{array}{c}\text { Economy } \\
\text { with aging }\end{array}$ \\
\hline Capital (per capita) & - & $-10.2 \%$ \\
\hline Labor (per capita) & - & $-10.1 \%$ \\
\hline Average work hours & - & $+0.4 \%$ \\
\hline Wage & - & $-0.04 \%$ \\
\hline Interest rate $(\%)$ & $5.54 \%$ & $5.55 \%$ \\
\hline Labor income tax: $\tau^{l}+\tau^{s s}+\tau^{\text {med }}(\%)$ & $35.0 \%$ & $43.6 \%$ \\
\hline Social Security budget balance (\% of GDP) & $+0.48 \%$ & $-3.47 \%$ \\
\hline Average assets at 62 (in $2008 \$ 1,000)$ & $\begin{array}{r}277.6 \\
-\end{array}$ & $\begin{array}{r}214.1 \\
-22.9 \% \\
\end{array}$ \\
\hline \multicolumn{3}{|l|}{ Retirement (Social Security already claimed) } \\
\hline at 62 & $49.9 \%$ & $37.4 \%$ \\
\hline by 66 & $98.1 \%$ & $94.8 \%$ \\
\hline by 69 & $100.0 \%$ & $100.0 \%$ \\
\hline \multicolumn{3}{|l|}{ Labor force participation } \\
\hline Age $60-69$ & $49.8 \%$ & $50.2 \%$ \\
\hline Age 20-59 & $92.5 \%$ & $91.0 \%$ \\
\hline
\end{tabular}

Table 6 summarizes the effects of the three Social Security reforms we discussed above, but now in the economy with an older population. The changes in the table are with respect to the benchmark economy with aging, where we maintain the current Social Security system. A $50 \%$ benefit reduction increases aggregate capital by $17.5 \%$, much larger than the $9.9 \%$ increase under the same experiment in the economy without aging. Given the longer life in this economy, they would have to accumulate more savings in order to supplement old age consumption. The response in the labor supply is larger as well and the participation rate of the elderly at age $60-69$ will rise from $50.2 \%$ to $66.8 \%$ by 16.6 percentage points, compared to 11.7 percentage points in the benchmark economy with no aging. More individuals will postpone retirement and the claim at the earliest retirement age will fall to only $17.1 \%$ of the retirees. The budget of the program will improve relative to the benchmark with aging and the deficit of the program will decline 
significantly, but an annual deficit of the program remains in the order of $1.62 \%$ of GDP and the funding must be supplemented by the general government budget. ${ }^{28}$

The effect of the increase in the early retirement age is small as before. The participation of the elderly will rise by 1.8 percentage points, even smaller than the rise of 2.6 percentage points in the benchmark economy. Since fewer people claim at age 62 in the first place, not many people would be affected by the reform. When the normal retirement age is raised by 2 years, which implies a lower benefit for a given retirement age, both saving and labor participation increase by a greater magnitude than in the same experiment in the economy without aging, for the same reason as the larger effects of the benefit cut. Individuals now have to work longer and save more in order to accumulate enough stock of savings for their old-age consumption.

Table 6: Effects of Social Security reforms in economy with aging

\begin{tabular}{|c|c|c|c|c|}
\hline & $\begin{array}{l}\text { Benchmark } \\
\text { with aging }\end{array}$ & $\begin{array}{l}\text { Benefit } \\
50 \% \Downarrow\end{array}$ & $\begin{array}{c}\text { ERA } \\
62 \rightarrow 64\end{array}$ & $\begin{array}{c}\text { NRA } \\
66 \rightarrow 68\end{array}$ \\
\hline Aggregate capital & - & $+17.5 \%$ & $-0.35 \%$ & $+4.2 \%$ \\
\hline Aggregate labor & - & $+5.7 \%$ & $+0.08 \%$ & $+1.6 \%$ \\
\hline Average work hours & - & $+0.4 \%$ & $-0.07 \%$ & $+0.1 \%$ \\
\hline Wage & - & $+3.9 \%$ & $-0.15 \%$ & $+0.9 \%$ \\
\hline Interest rate $(\%)$ & $5.55 \%$ & $4.60 \%$ & $5.59 \%$ & $5.31 \%$ \\
\hline Labor income tax: $\tau^{l}+\tau^{s s}+\tau^{m e d}(\%)$ & $43.6 \%$ & $32.0 \%$ & $43.7 \%$ & $40.7 \%$ \\
\hline Social Security budget balance (\% of GDP) & $-3.47 \%$ & $-1.62 \%$ & $-3.50 \%$ & $-2.15 \%$ \\
\hline Average assets at 62 (in $2008 \$ 1,000)$ & $\begin{array}{r}214.1 \\
-\end{array}$ & $\begin{array}{r}281.6 \\
+31.5 \%\end{array}$ & $\begin{array}{r}213.7 \\
-0.2 \%\end{array}$ & $\begin{array}{r}232.7 \\
+8.7 \%\end{array}$ \\
\hline \multicolumn{5}{|l|}{ Retirement (Social Security already claimed) } \\
\hline at 62 & $37.4 \%$ & $17.1 \%$ & - & $27.1 \%$ \\
\hline by 66 & $94.8 \%$ & $81.2 \%$ & $94.4 \%$ & $79.8 \%$ \\
\hline by 69 & $100.0 \%$ & $100.0 \%$ & $100.0 \%$ & $100.0 \%$ \\
\hline \multicolumn{5}{|l|}{ Labor force participation } \\
\hline Age $60-69$ & $50.2 \%$ & $66.8 \%$ & $52.0 \%$ & $54.7 \%$ \\
\hline Age 20-59 & $91.0 \%$ & $94.4 \%$ & $90.7 \%$ & $92.2 \%$ \\
\hline
\end{tabular}

\footnotetext{
${ }^{28}$ According to the SSA's 2009 OASDI Trustees Report, an immediate and permanent reduction of benefits by $13 \%$ is necessary for the system to "remain solvent throughout the 75 -year projection period." The estimate does not take into account the effect on the Trust Funds after the 75-year projection period and the report concludes "significantly larger changes would be required to maintain solvency beyond 75 years." When we simulate the model with a benefit cut of $13 \%$, while keeping the social security tax at the benchmark level, the program budget will improve and the surplus will rise to $1.33 \%$ of GDP. With the demographic change, however, it will run an annual deficit of $2.06 \%$ of GDP, lower than the deficit of $3.47 \%$ if the benefit remains at the current level, but confirming the statement of the Report that a much larger change is necessary for the system to be self-financed.
} 


\subsection{Partial equilibrium analysis}

In order to understand the effects of general equilibrium adjustment in prices, we conduct sensitivity analysis and study the reform effects under the assumption of fixed prices. Table 7 summarizes the simulation result of the three reforms where the interest rate and wage are fixed at their benchmark levels.

When the benefit is reduced by $50 \%$, total assets net of government debt will rise by $40 \%$, significantly more than the rise of $10 \%$ in the benchmark experiment with a general equilibrium price adjustment. ${ }^{29}$ Since we fix the interest rate at an exogenously high level, individuals would allocate more of their resources to savings. The wage, on the other hand, is fixed at the low benchmark level. The additional saving to supplement the reduced Social Security benefit will be provided through the adjustment of intertemporal allocations rather than the increase in the labor supply. In fact, the strong wealth effect from the massive rise in saving will dominate the substitution effect from the higher aftertax wage and aggregate labor supply declines slightly, differently from the result under the general equilibrium economy in which the reform increased the aggregate labor by $3 \%$.

No significant change is observed in the reform of raising the early retirement age from 62 to 64, since factor prices hardly move in this experiment. The effects of the normal retirement age experiment are similar to those with the benefit cut. The capital stock will rise by more than in the general equilibrium model and labor supply and participation will not change much.

\footnotetext{
${ }^{29}$ Note that the assets net of the government debt does not coincide with the capital used in production since the market for capital does not clear. In the table, we express it as the total assets of individuals net of the government debt so that the results are comparable to those under experiments in general equilibrium.
} 
Table 7: Effects of Social Security reforms with fixed prices

\begin{tabular}{|c|c|c|c|c|}
\hline & Benchmark & $\begin{array}{l}\text { Benefit } \\
50 \% \Downarrow\end{array}$ & $\begin{array}{c}\text { ERA } \\
62 \rightarrow 64\end{array}$ & $\begin{array}{c}\text { NRA } \\
66 \rightarrow 68\end{array}$ \\
\hline Assets net of debt & - & $+40.3 \%$ & $-1.00 \%$ & $+9.9 \%$ \\
\hline Labor & - & $-0.4 \%$ & $+0.35 \%$ & $-0.1 \%$ \\
\hline Average work hours & - & $-0.3 \%$ & $-0.04 \%$ & $-0.03 \%$ \\
\hline Labor income tax: $\tau^{l}+\tau^{s s}+\tau^{m e d}(\%)$ & $35.0 \%$ & $27.2 \%$ & $34.9 \%$ & $33.0 \%$ \\
\hline Average assets at 62 (in $2008 \$ 1,000)$ & $\begin{array}{r}277.6 \\
-\end{array}$ & $\begin{array}{r}393.0 \\
+41.6 \%\end{array}$ & $\begin{array}{r}275.2 \\
-0.9 \%\end{array}$ & $\begin{array}{r}308.6 \\
+11.2 \%\end{array}$ \\
\hline \multicolumn{5}{|c|}{ Retirement (Social Security already claimed) } \\
\hline $\begin{array}{l}\text { at } 62 \\
\text { by } 66 \\
\text { by } 69\end{array}$ & $\begin{array}{r}49.9 \% \\
98.1 \% \\
100.0 \%\end{array}$ & $\begin{array}{r}39.9 \% \\
97.4 \% \\
100.0 \%\end{array}$ & $\begin{array}{r}- \\
97.8 \% \\
100.0 \%\end{array}$ & $\begin{array}{r}41.9 \% \\
88.6 \% \\
100.0 \%\end{array}$ \\
\hline \multicolumn{5}{|l|}{ Labor force participation } \\
\hline $\begin{array}{l}\text { Age } 60-69 \\
\text { Age } 20-59\end{array}$ & $\begin{array}{l}49.8 \% \\
92.5 \%\end{array}$ & $\begin{array}{l}52.4 \% \\
91.7 \%\end{array}$ & $\begin{array}{l}52.7 \% \\
92.4 \%\end{array}$ & $\begin{array}{l}49.9 \% \\
92.3 \%\end{array}$ \\
\hline
\end{tabular}

\section{Conclusion}

In this paper we build a quantitative general equilibrium model of overlapping generations of individuals who make decisions on consumption, saving, labor supply on both extensive and intensive margins and Social Security benefit claims. It captures rich cross-sectional heterogeneity among individuals in the dimensions of wealth, labor productivity, health, employer provided health insurance and average earnings that determine the Social Security benefit. The model matches the pattern of labor force participation and Social Security claiming behavior of old-age individuals as in the data, where more than $50 \%$ of retirees claim benefits at the earliest retirement age of 62 and the participation rate declines rapidly as they approach the retirement ages.

We show that Social Security reform can have a large impact on the participation of the elderly and their benefit take-up. A 50\% reduction of the payroll tax rate and benefits is shown to have a significant effect on both saving and labor supply. The participation among older workers in their 60 s rises from $50 \%$ to $62 \%$. More individuals choose to postpone the benefit take-up and the claim rate at age 62 plummets from $50 \%$ to less than $30 \%$. These effects are magnified significantly in a model under the demographic structure projected for 2080, where the life expectancy is longer and the dependency ratio is higher, since individuals will then face an additional need for savings to finance their old age consumption and self-insure against medical expenditure risks for a longer period of time.

Currently the Social Security program runs a surplus and revenues from payroll taxes exceed the benefits paid to retirees. The surplus is expected to decline over the 
next decade and eventually turn to a deficit. Our model predicts an annual budget deficit of 3.5\% of GDP under the 2080 demographics unless a reform is undertaken. A 50\% reduction in the size of the current unfunded system will reduce the deficit to $1.6 \%$ of GDP. Increasing the normal retirement age from 66 to 68 will also help reduce the budget deficit since more individuals will postpone the retirement and the benefit spending will fall, while labor participation among the old-age individuals rises and the payroll tax revenues increase. An increase in the early retirement age will not have any significant effect on the budget of the Social Security system, since the benefits will be permanently raised by forcing individuals to postpone retirement.

\section{References}

Altonji, J. G. (1986). Intertemporal substitution of labor supply: Evidence from microdata. Journal of Political Economy 94(3), 176-215.

Attanasio, O. P., S. Kitao, and G. L. Violante (2009). Financing Medicare: A general equilibrium analysis. In J. Shoven (Ed.), Demography and the Economy. University of Chicago Press. forthcoming.

Auerbach, A. J. and L. J. Kotlikoff (1987). Dynamic Fiscal Policy. Cambridge: Cambridge University Press.

Bell, F. C. and M. L. Miller (2005). Life tables for the United States social security area 1900-2100.

Benitez-Sílva, H., D. S. Dwyer, F. Heiland, and W. C. Sanderson (2007). A dynamic model of retirement and Social Security reform expectations: A solution to the new early retirement puzzle. Working Paper.

Benitez-Sílva, H. and F. Heiland (2007a). Early claiming of Social Security benefits and labor supply behaviour of older Americans. Applied Economics iFirst, 1-17.

Benitez-Sílva, H. and F. Heiland (2007b). The social security earnings test and work incentives. Journal of Policy Analysis and Management 26(3), 527-555.

Blau, D. M. and D. B. Gilleskie (2006). Health insurance and retirement of married couples. Journal of Applied Econometrics 21(7), 935-953.

Browning, M., L. P. Hansen, and J. J. Heckman (1999). Micro data and general equilibrium models. In J. B. Taylor and M. Woodford (Eds.), Handbook of Macroeconomics, Volume 1A, Chapter 8. Amsterdam: North-Holland.

Budría Rodríguez, S., J. Díaz-Giménez, V. Quadrini, and J.-V. Ríos-Rull (2002). Updated facts on the U.S. distributions of earnings, income, and wealth. Federal Reserve Bank of Minneapolis, Quarterly Review 26(3), 2-35.

Burkhauser, R. V., K. A. Couch, and J. W. Phillips (1996). Who takes early social security benefits? the economic and health characteristics of early beneficiaries. The Gerontologist 36, 789-799.

Conesa, J. C. and D. Krueger (1999). Social security with heterogeneous agents. Review of Economic Dynamics 2(4), 757-795. 
De Nardi, M. (2003). Wealth inequality and intergenerational links. Review of Economic Studies $71(3)$, 743-768.

De Nardi, M., E. French, and J. B. Jones (2009). Why do the elderly save? the role of medical expenses. NBER Working Paper 15149.

De Nardi, M., S. İmrohoroğlu, and T. J. Sargent (1999). Projected U.S. demographics and social security. Review of Economic Dynamics 2(3), 575-615.

Deaton, A. (1991). Saving and liquidity constraints. Econometrica 59(5), 1221-1248.

Díaz-Giménez, J. and J. Díaz-Saavedrac (2009). Delaying retirement in Spain. Review of Economic Dynamics 12(1), 147-167.

Domeij, D. and M. Floden (2006). The labor-supply elasticity and borrowing constraints: Why estimates are biased. Review of Economic Dynamics 9(2), 242-262.

French, E. (2005). The effects of health, wealth, and wages on labour supply and retirement behaviour. Review of Economic Studies 72(2), 395-427.

Gourinchas, P.-O. and J. A. Parker (2002). Consumption over the life cycle. Econometrica $70(1), 47-89$.

Gustman, A. L. and T. L. Steinmeier (2005). The social security early entitlement age in a structural model of retirement and wealth. Journal of Public Economics 89(2-3), 441-463.

Hansen, G. D. (1993). The cyclical and secular behaviour of the labour input: Comparing efficiency units and hours worked. Journal of Applied Econometrics 8(1), 71-80.

Heathcote, J., K. Storesletten, and G. L. Violante (2008). The macroeconomic implications of rising wage inequality in the United States. Working Paper.

Huang, H., S. İmrohoroğlu, and T. J. Sargent (1997). Two computations to fund social security. Macroeconomic Dynamics 1, 7-44.

Hubbard, R. G. and K. Judd (1987). Social security and individual welfare: Precautionary saving, borrowing constraints, and the payroll tax. American Economic Review 177(4), 630-646.

Hubbard, R. G., J. Skinner, and S. P. Zeldes (1995). Precautionary saving and social insurance. Journal of Political Economy 103(2), 360-399.

İmrohoroğlu, A., S. İmrohoroğlu, and D. Joines (1995). A life cycle analysis of social security. Economic Theory 6(1), 83-114.

İmrohoroğlu, S. and S. Kitao (2009). Labor supply elasticity and social security reform. Journal of Public Economics 93(7-8), 867-878.

Ippolito, R. A. (1997). Pension Plans and Employee Performance. Chicago: University of Chicago Press.

Jeske, K. and S. Kitao (2009). U.S. tax policy and health insurance demand: Can a regressive policy improve welfare? Journal of Monetary Economics 56(2), 210-221. 
Kotlikoff, L., K. Smetters, and J. Walliser (1999). Privatizing social security in the united statescomparing the options. Review of Economic Dynamics 2(3), 532-574.

MaCurdy, T. E. (1981). An empirical model of labor supply in a life-cycle setting. Journal of Political Economy 89(6), 1059-1085.

Mendoza, E. G., A. Razin, and L. L. Tesar (1994). Effective tax rates in macroeconomics: Cross-country estimates of tax rates on factor incomes and consumption. Journal of Monetary Economics 34(3), 297-323.

Palumbo, M. G. (1999). Uncertain medical expenses and precautionary saving near the end of the life cycle. Review of Economic Studies 66(2), 395-421.

Prescott, E. C., R. Rogerson, and J. Wallenius (2009). Lifetime aggregate labor supply with endogenous workweek length. Review of Economic Dynamics 12(1), 23-36.

Ríos-Rull, J.-V. (1996). Life cycle economies and aggregate fluctuations. Review of Economic Studies 63, 465-489.

Rogerson, R. and J. Wallenius (2009). Micro and macro elasticities in a life cycle model with taxes. Journal of Economic Theory. forthcoming.

Rust, J. and C. Phelan (1997). How social security and Medicare affect retirement behavior in a world of incomplete markets. Econometrica 65(4), 781-831.

van der Klaauw, W. and K. Wolpin (2008). Social security and the savings and retirement behavior of low income households. Journal of Econometrics 145(1-2), $21-42$.

Waldron, H. (2004). Heterogeneity in health and mortality risk among early retiree men. Working Paper. 


\section{A Social Security rules and reform uncertainty}

In this section, we will run sensitivity analysis on the features of the Social Security system and the benefit rules in order to understand how they affect the life-cycle decisions of individuals, including the timing of benefit claiming and labor force participation.

Earnings test (A1): To identify the role of the earnings test, we run the benchmark model without the earnings test, where Social Security benefits are no longer subject to taxation no matter how much one earns while receiving benefit prior to the normal retirement age. The results are shown in column labeled A1 in Table 8. The benefit claim at the earliest retirement age will rise significantly from $49.9 \%$ to $76.7 \%$. Those who postpone the claim in the benchmark economy since they intend to earn more than the threshold of the earnings test may be inclined to claim benefits early, now that there is no penalty on earnings. The participation rate among the elderly will rise by $1.5 \%$. The effect on the participation is smaller than what other papers have found, in which only the taxation part of the earnings test is captured but not the "undoing" part of the test which will restores the penalty imposed by the ARF. In other words, the participation would have been lower in the benchmark economy if there was not the second part of the earnings test and we would have observed a larger effect in participation by eliminating the earnings test. Benitez-Sílva et al. (2007) study the effect of the ARF adjustment associated with the earnings test and show that the adjustment will raise the participation of the elderly at ages between 62 and 65 by 4 to 9 percentage points.

Actuarial Reduction Factor (ARF) (A2): In this experiment, we assume that there is no penalty by the ARF for early retirement and try to quantify the negative effect of the ARF on the labor force participation of the elderly. There would be less incentive to wait until the normal retirement age to retire since one would simply forgo the benefits during the years between 62 and 66 . The claim at the earliest retirement age will jump to $96 \%$. The cost of providing permanently higher benefits for the large number of early retirees is reflected in the change in the labor income tax, which increases by approximately 5 percentage points to $39.8 \%$. Coupled with a greater annuity provided by the Social Security, both savings and labor supply will fall. Aggregate capital declines by $6.7 \%$ and participation of the elderly will drop significantly from $50 \%$ to $30 \%$.

Early retirement (A3): We now assume that early retirement is no longer possible and the earliest age to claim the benefit is the normal retirement age of 66 . The results of this experiment are similar to those of the reform to increase the earliest retirement age to 64. Macro variables barely change under the experiment. The tax rate remains almost unchanged since the average benefits are higher by forcing them to retire late and the total spending does not change much.

Uncertainty about future Social Security system (A4): In this experiment we incorporate some uncertainty about the future of the Social Security system and individuals' expectation about the reform. We assume that individuals expect a reform 
to occur in the next period with a certain probability and if it does, the benefits of new retirees will be permanently reduced. In the experiment, we set the probability of reform at $10 \%$ and the benefit will be reduced by $5 \% .{ }^{30}$ The effects are negligibly small, except for the early retirement at age 62 that increases by $8.7 \%$. Note that we made a rather strong assumption that the benefit will not be affected by the reform if an individual has already claimed the benefits before the reform happens, driving an additional incentive to claim early and fix the benefit for the rest of their life. If we allow for an equivalent adjustment for those who are already retired, we expect the change in the retirement to be much smaller.

\footnotetext{
${ }^{30}$ For simplicity, we compute the continuation value when the reform happens by assuming that the same aggregate conditions including the factor prices and fiscal variables would prevail as in the stationary equilibrium and we do not compute an explicit transition dynamics in response to the change in benefits.
} 


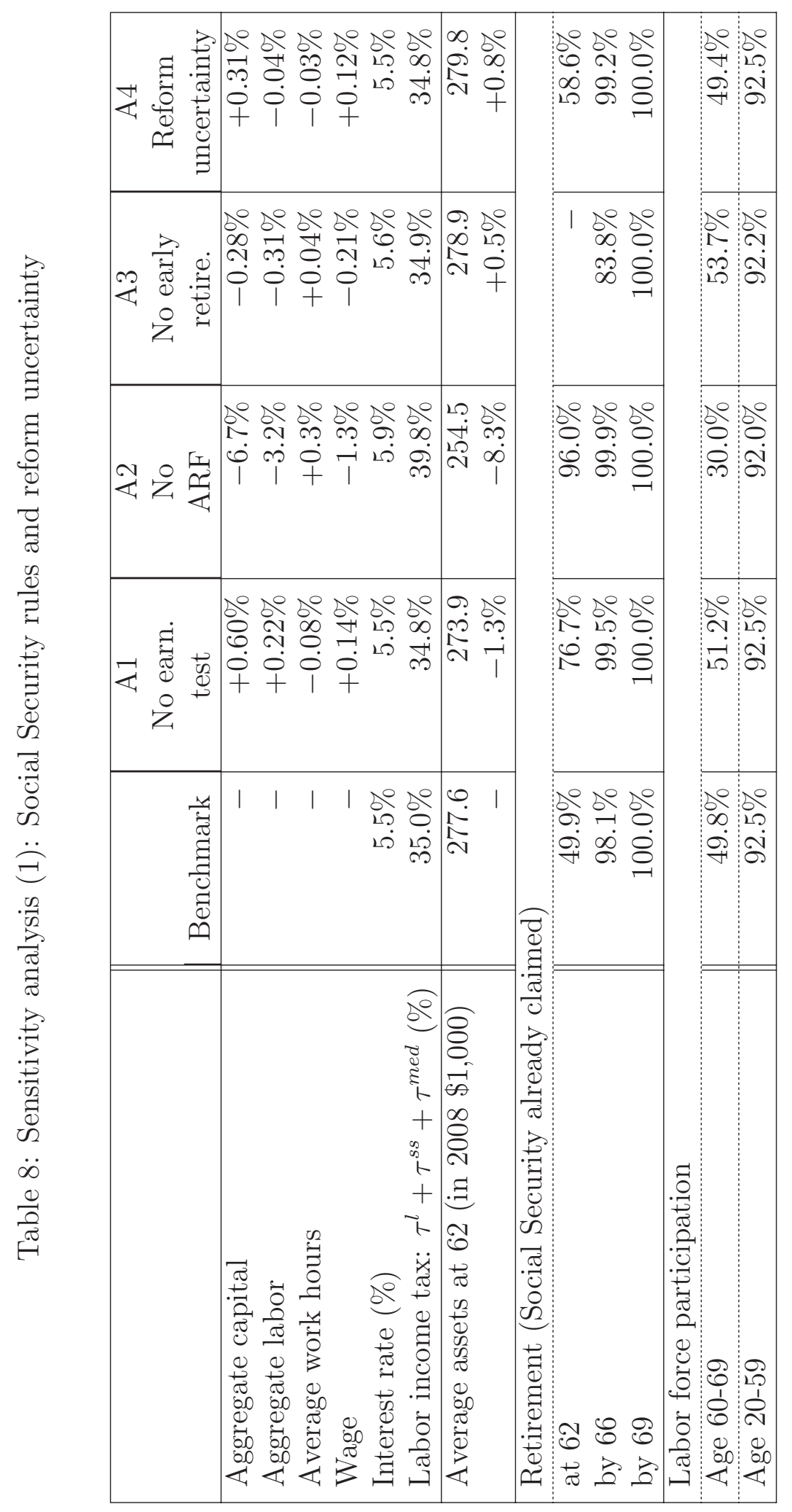




\section{B More sensitivity analysis}

In this section we conduct sensitivity analysis to study how various features of the model besides the rules of the Social Security system affect the outcome of the model and the pattern of retirement and labor force participation.

Health expenditures and shocks (B1 and B2): In order to understand the role of health expenditures and their variability, we compute an equilibrium in which health expenditure uncertainty is eliminated (B1). We let agents face a deterministic profile of medical expenditures that depends only on age. The level of expenditures at each age is based on the average expenditures from the distribution used in the benchmark model. We also assume away private health insurance. Second, we completely eliminate the expenditures from the model (B2). ${ }^{31}$ The results are shown in Table 9 in columns labeled B1 and B2. In B1, aggregate capital and labor supply will fall but the change is less than a percentage point. Even without the uncertainty, individuals will still need to accumulate enough savings in order to finance the expenditures that rise rapidly with age. In B2, the saving will fall significantly and aggregate capital and labor decline by $6.5 \%$ and $8.5 \%$ respectively. The labor participation of the elderly at age 60-69 will fall by more than $10 \%$ to $37.9 \%$. The decline is more pronounced among the elderly in bad health, who incur more disutility from working, since they do not have to work as hard as they did in the benchmark in order to pay for the high medical costs. Their participation rate falls from $28.5 \%$ in the benchmark to $10.6 \%$.

Consumption floor $\underline{c}$ (B3): In order to assess the sensitivity of our results to the level of the consumption floor, we compute an equilibrium in which the floor is set at $\$ 1,500$, half of the level in the benchmark economy. Since the consequence of running out of assets is more severe, there will be a stronger incentive to accumulate buffer stock savings against expenditure shocks and aggregate capital will rise by about $1 \%$. The labor force participation will rise slightly but there is not much change in the benefit take-up.

Bequest motives (B4): We now completely eliminate warm-glow bequest motives by setting the value of parameter $\psi_{2}$ to 0 . Individuals will begin to quickly run down the assets after mid-50s and aggregate capital will fall by as much as $22 \%$. The participation rate of the elderly will also fall significantly from $49.8 \%$ to $38.5 \%$.

Private health insurance (B5): To understand the role of health insurance, we run a model assuming that all agents pay the entire gross expenditures out of pocket and there is no employer-provided health insurance. As shown in Table 9, there is a decline in the labor force participation, which is concentrated among those in bad health status. Since the coverage by the employer-based health insurance was conditional on employment, some individuals, especially those in bad health and expecting to incur larger expenditures stayed at work mainly because they would like to keep the coverage. There is an incentive to do so at least until age 65, when everyone becomes eligible to be covered by Medicare,

\footnotetext{
${ }^{31}$ In B2, we assume away both health insurance and Medicare.
} 
which is less generous in terms of coverage rate than the employer based insurance, but still covers a significant amount of expenditures. The job exit rate (defined as the change in participation rate) at age 65 falls from $19.4 \%$ in the benchmark economy to $7.5 \%$ in the economy without private health insurance. Rust and Phelan (1997) also emphasize the distortions on the participation decisions caused by the Medicare eligibility. Our finding is consistent with theirs, though the magnitude of the exit at this particular age is smaller in the benchmark, since the agents in our model can also self-insure against the expenditure risks by accumulating riskless assets, whereas Rust and Phelan (1997) focus on poor households and abstract from saving decisions.

Medicare (B6): We assume there is no Medicare. All individuals above age 65 pay the entire gross expenditures out of pocket. The additional expenditure risks and the need to cover large expenditures at old ages will raise the precautionary saving demand and aggregate capital will increase by $3.6 \%$. The early benefit claiming at age 62 will fall from $49.9 \%$ to $43.8 \%$. More individuals choose to postpone the benefit take-up and increase the value of annuity at older ages in order to supplement the loss of insurance provided by Medicare.

Rise in medical expenditures (B7): Medical expenditures have been rising much faster than the general output of the economy in recent years. In order to understand the effect of a further rise in the medical cost relative to the cost of other goods, we run an experiment where the real expenditures rise by $50 \%$ universally. The last column of Table 9 shows the results. Despite the rise in the resources allocated to the medical expenditures, aggregate capital barely changes and declines only by $0.4 \%$. It implies that individuals allocate relatively more of their income towards savings. In fact, non-medical consumption drops by as much as $5.7 \%$ in the economy with the high expenditures. Early retirement at age 62 will fall by about 5 percentage points and the labor participation of the elderly will rise by 3.2 percentage points. 


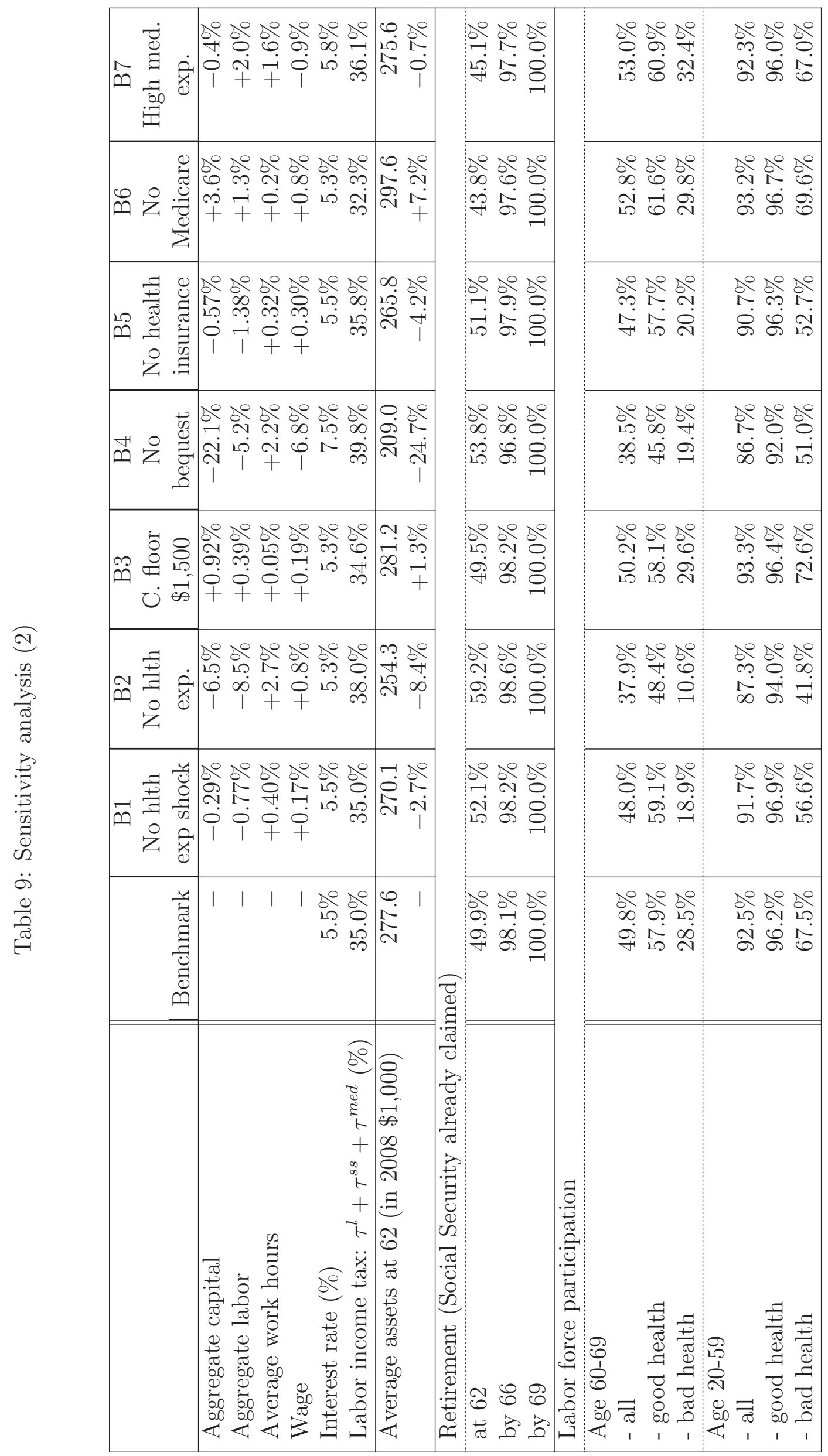




\section{Labor supply elasticity}

In this section, we study the sensitivity of our main findings regarding the effects of Social Security reforms to alternative values of the Frisch elasticity of labor supply. The estimates of this important parameter in the literature lie in a wide range. Early estimates that use male samples such as MaCurdy (1981) and Altonji (1986) are very small, between 0.035 and 0.567. More recent estimates are higher and close to unity; see for example Domeij and Floden (2006) and Browning et al. (1999) for a survey. We chose the value of the Frisch elasticity $\gamma$ at 0.5 in the benchmark calibration, which lies in the range of classic micro estimates and experiment in this section with two alternative values of 0.25 and 1.0. Since the purpose of the sensitivity analysis is to compare the quantitative effects of the Social Security reforms under alternative degrees of labor supply elasticity, we recalibrate the parameters of the economy to match the same aggregate statistics that we used as calibration targets as we discussed in section $4 .^{32}$

Results are summarized in Tables 10 and 11. Across the three reform experiments, results are very similar to those under the benchmark calibration reported in Table 4, not only qualitatively but also quantitatively. The finding that the aggregate effects are not sensitive to the value of labor supply elasticity is consistent with the results of Imrohoroğlu and Kitao (2009).

\footnotetext{
${ }^{32}$ More precisely, we calibrate the value of TFP $A$, discount factor $\beta$, the preference weight parameter $\chi$, weight on bequest utility $\psi_{1}$ and cost of participation $\phi$ to match the target that corresponds to each parameter. The re-calibrated values for $\left\{A, \beta, \chi, \psi_{1}, \phi\left(h^{g}\right), \phi\left(h^{b}\right)\right\}$ are $\{1.6,0.966,270,26,0.64,1.05\}$ for $\gamma=0.25$ and $\{1.6,0.963,10,27,0.33,0.7\}$ for $\gamma=1.0$.
} 
Table 10: Effects of Social Security reforms: Frisch elasticity $\gamma=0.25$

\begin{tabular}{|c|c|c|c|c|}
\hline & Benchmark & $\begin{array}{l}\text { Benefit } \\
50 \% \Downarrow\end{array}$ & $\begin{array}{c}\text { ERA } \\
62 \rightarrow 64\end{array}$ & $\begin{array}{c}\text { NRA } \\
66 \rightarrow 68\end{array}$ \\
\hline Aggregate capital & - & $+9.7 \%$ & $+0.34 \%$ & $+2.7 \%$ \\
\hline Aggregate labor & - & $+2.6 \%$ & $+0.29 \%$ & $+0.7 \%$ \\
\hline Average work hours & - & $+0.1 \%$ & $-0.04 \%$ & $+0.03 \%$ \\
\hline Wage & - & $+2.4 \%$ & $+0.02 \%$ & $+0.7 \%$ \\
\hline Interest rate $(\%)$ & $5.41 \%$ & $4.81 \%$ & $5.40 \%$ & $5.24 \%$ \\
\hline Labor income tax: $\tau^{l}+\tau^{s s}+\tau^{m e d}(\%)$ & $34.9 \%$ & $27.9 \%$ & $34.3 \%$ & $32.8 \%$ \\
\hline Social Security budget balance ( $\%$ of GDP) & $+0.51 \%$ & $+0.31 \%$ & $+0.58 \%$ & $+1.34 \%$ \\
\hline Average assets at $62($ in $2008 \$ 1,000)$ & $\begin{array}{r}283.1 \\
-\end{array}$ & $\begin{array}{r}335.4 \\
+18.5 \%\end{array}$ & $\begin{array}{r}284.3 \\
+0.4 \%\end{array}$ & $\begin{array}{r}299.5 \\
+5.8 \%\end{array}$ \\
\hline \multicolumn{5}{|l|}{ Retirement (Social Security already claimed) } \\
\hline at 62 & $45.5 \%$ & $27.2 \%$ & - & $35.6 \%$ \\
\hline by 66 & $97.3 \%$ & $93.4 \%$ & $96.9 \%$ & $86.1 \%$ \\
\hline by 69 & $100.0 \%$ & $100.0 \%$ & $100.0 \%$ & $100.0 \%$ \\
\hline \multicolumn{5}{|l|}{ Labor force participation } \\
\hline Age 60-69 & $50.0 \%$ & $62.1 \%$ & $52.8 \%$ & $52.6 \%$ \\
\hline Age 20-59 & $92.8 \%$ & $94.2 \%$ & $92.7 \%$ & $93.2 \%$ \\
\hline
\end{tabular}


Table 11: Effects of Social Security reforms: Frisch elasticity $\gamma=1.0$

\begin{tabular}{|c|c|c|c|c|}
\hline & Benchmark & $\begin{array}{l}\text { Benefit } \\
50 \% \Downarrow\end{array}$ & $\begin{array}{c}\text { ERA } \\
62 \rightarrow 64\end{array}$ & $\begin{array}{c}\text { NRA } \\
66 \rightarrow 68\end{array}$ \\
\hline Aggregate capital & - & $+9.9 \%$ & $+0.40 \%$ & $+3.1 \%$ \\
\hline Aggregate labor & - & $+2.9 \%$ & $+0.35 \%$ & $+0.9 \%$ \\
\hline Average work hours & - & $+0.4 \%$ & $-0.03 \%$ & $+0.07 \%$ \\
\hline Wage & - & $+2.4 \%$ & $+0.02 \%$ & $+0.8 \%$ \\
\hline Interest rate $(\%)$ & $5.51 \%$ & $4.92 \%$ & $5.51 \%$ & $5.31 \%$ \\
\hline Labor income tax: $\tau^{l}+\tau^{s s}+\tau^{\text {med }}(\%)$ & $34.9 \%$ & $27.9 \%$ & $33.9 \%$ & $32.2 \%$ \\
\hline Social Security budget balance (\% of GDP) & $+0.53 \%$ & $+0.32 \%$ & $+0.59 \%$ & $+1.37 \%$ \\
\hline Average assets at 62 (in $2008 \$ 1,000)$ & $\begin{array}{r}283.8 \\
-\end{array}$ & $\begin{array}{r}340.1 \\
+20.1 \%\end{array}$ & $\begin{array}{r}287.9 \\
+1.7 \%\end{array}$ & $\begin{array}{r}302.5 \\
+6.8 \%\end{array}$ \\
\hline \multicolumn{5}{|l|}{ Retirement (Social Security already claimed) } \\
\hline at 62 & $54.5 \%$ & $32.6 \%$ & - & $42.7 \%$ \\
\hline by 66 & $97.3 \%$ & $93.4 \%$ & $96.7 \%$ & $89.2 \%$ \\
\hline by 69 & $100.0 \%$ & $100.0 \%$ & $100.0 \%$ & $100.0 \%$ \\
\hline \multicolumn{5}{|l|}{ Labor force participation } \\
\hline Age $60-69$ & $49.9 \%$ & $61.5 \%$ & $52.9 \%$ & $52.8 \%$ \\
\hline Age 20-59 & $92.5 \%$ & $94.0 \%$ & $92.5 \%$ & $93.1 \%$ \\
\hline
\end{tabular}




\section{RECENT WORKING PAPERS FROM THE}

\section{CENTER FOR RETIREMENT RESEARCH AT BOSTON COLLEGE}

\section{How Much Is Enough? The Distribution of Lifetime Health Care Costs}

Anthony Webb and Natalia Zhivan, February 2010

Impact of Immigration on the Distribution of American Well-Being Gary Burtless, December 2009

Actual and Anticipated Inheritance Receipts

Norma B. Coe and Anthony Webb, December 2009

Will Automatic Enrollment Reduce Employer Contributions to 401(k) Plans Mauricio Soto and Barbara A. Butrica, December 2009

How Seniors Change Their Asset Holdings During Retirement

Karen Smith, Mauricio Soto, and Rudolph G. Penner, December 2009

Retirement Security and the Stock Market Crash: What Are the Possible Outcomes?

Barbara A. Butrica, Karen E. Smith, and Eric J. Toder, November 2009

Fees and Trading Costs of Equity Mutual Funds in 401(k) Plans and Potential Savings from ETFs and Commingled Trusts

Richard W. Kopcke, Francis Vitagliano, and Zhenya S. Karamcheva, November 2009

Work Ability and the Social Insurance Safety Net in the Years Prior to Retirement Richard W. Johnson, Melissa M. Favreault, and Corina Mommaerts, November 2009

Dutch Pension Funds in Underfunding: Solving Generational Dilemmas

Niels Kortleve and Eduard Ponds, November 2009

The Wealth of Older Americans and the Sub-Prime Debacle

Barry Bosworth and Rosanna Smart, November 2009

Insult to Injury: Disability, Earnings, and Divorce Perry Singleton, November 2009

An Update on 401(k) Plans: Insights from the 2007 Survey of Consumer Finance Alicia H. Munnell, Richard W. Kopcke, Francesca Golub-Sass, and Dan Muldoon, November 2009 